\title{
CONVENTIONAL COMBUSTION ENVIRONMENTAL ASSESSMENT PROGRAM
}

\author{
Wade H. Ponder \\ Industrial Environmental Research Laboratory \\ Research Triangle Park, North Carolina \\ Environmental Protection Agency
}

\author{
Deepak C. Kenkeremath \\ Metrek Division of The MITRE Corporation
}

1820 Dolley Madison Blvd., McLean, Virginia 22102

M78-44 Rev. 1

SEPTEMBER 1978

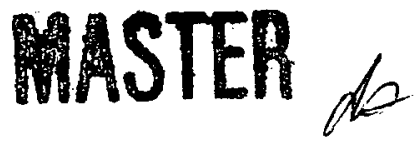




\section{DISCLAIMER}

This report was prepared as an account of work sponsored by an agency of the United States Government. Neither the United States Government nor any agency Thereof, nor any of their employees, makes any warranty, express or implied, or assumes any legal liability or responsibility for the accuracy, completeness, or usefulness of any information, apparatus, product, or process disclosed, or represents that its use would not infringe privately owned rights. Reference herein to any specific commercial product, process, or service by trade name, trademark, manufacturer, or otherwise does not necessarily constitute or imply its endorsement, recommendation, or favoring by the United States Government or any agency thereof. The views and opinions of authors expressed herein do not necessarily state or reflect those of the United States Government or any agency thereof. 


\section{DISCLAIMER}

Portions of this document may be illegible in electronic image products. Images are produced from the best available original document. 


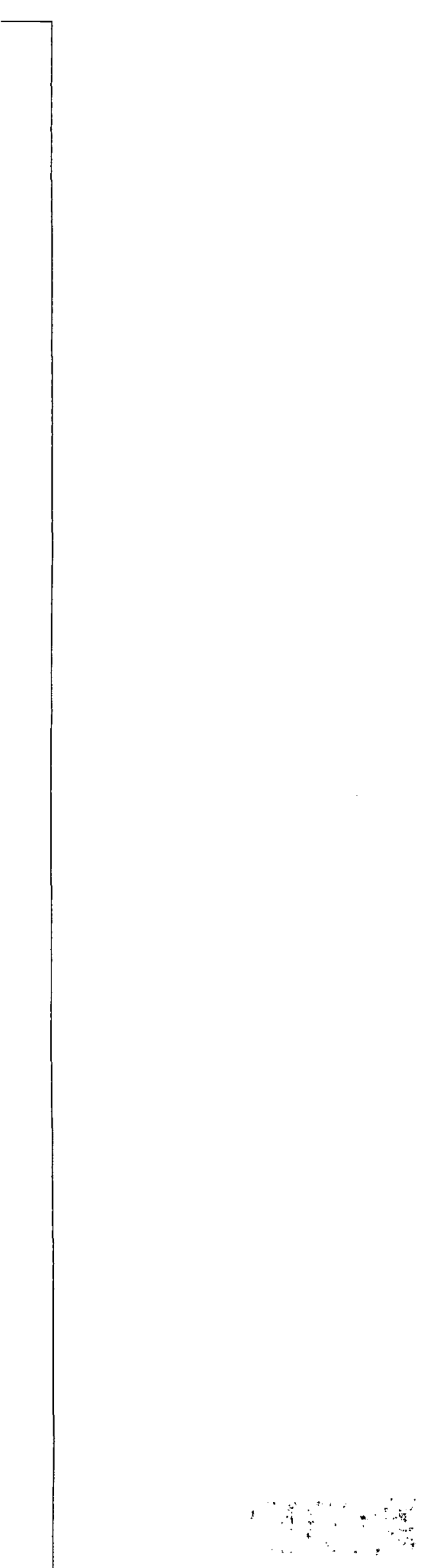


TABLE OF CONTENTS

Page

LIST OF ILLUSTRATIONS

LIST OF TABLES

iv

$\mathrm{V}$

I. INTRODUCTION 1

A. Background 1

B. Rationale for the Conventional Combustion

C. The CCEA Program and Its Objectives 5

II. A COMPREHENSIVE ENVIRONMENTAL ASSESSMENT METHODOLOGY 7

A. Environmental Assessment Definition and Objectives 7

B. Functional Activities 8

1. Generalized Environmental Assessment Methodology

2. Detailed Environmental Assessment Methodo logy

III. CCEA PROGRAM PLANNING .

A. Overall Planning Technique 35

B. Program Plan Developmental Effort 40

C. CCEA Program Planning Status 53

REFERENCES 


\section{LIST OF ILLUSTRATIONS}

Page

Figure Number

1

2

3

4

5

6

7

8

$9 A$

$9 \mathrm{~B}$

10

11

Generalized Environmental Assessment Methodology

Combustion Processes and Effluent Characterization (Step One)

Assessment of Health and Ecological Impacts (Step Two)

Health and Ecological Impacts Identification (First Activity, Step Two)

Development of Environmental Goals and Objectives (Second Activity, Step Two) Magnitude of Pollution Impacts (Fourth Activity, Step Two)

Alternative Control Strategy Evaluation (Step Three)

Comprehensive Environmental Assessment Methodology

Unified Conventional Combustion Environmental Assessment Program Planning Unified Conventional Combustion Environmental Assessment Program Planning 


\section{LIST OF TABLES}

Page

Table Number

1

2

3

4

5

6
Sample MEG Chart

Sample MEG Background Information Sheet Potential EPA-Sponsored CCEA Core Projects CCEA Program Environmental Assessment Element Code

Use Sector, Fuels, Combustion Process Type, Combustion Technology, and Pollutant Categories

Pollution Control Technology Categories
24

25

43

47

48

49 


\section{INTRODUCTION}

\section{A. Background}

The United States is one of the largest users of energy in the world. In 1976 more than $74.3 \times 10^{15} \mathrm{Btu}\left(78.4 \times 10^{18}\right.$ joules $)$ of energy were used in this country to heat and cool buildings, to operate transportation systems, and to power industry. ${ }^{1}$ By 1985, this figure is expected to increase by approximately 20 percent and by the year 2000, the United States is projected to increase its energy use to more than $100 \times 10^{15}$ Btu $\left(106 \times 10^{18} \text { joules }\right)^{2}$, which represents an increase of over $34 \%$ over the 1976 use rate.

Historically, fossil fuels have composed the largest segment of the nation's energy resources. In 1972, for example, fossil fuels supplied more than 95 percent of the total U.S. energy need; even with the anticipated growth in nuclear, solar, and geothermal energy sources, fossil fuels are still expected to supply approximately 70 percent of the demand by the turn of the century. ${ }^{3}$ These values illustrate the magnitude of this country's current and future reliance on fossil fuels to supply its vital energy needs.

Conventional methods of converting fossil fuels to usable forms of energy, however, are not without associated environmental penalties, The conventional combustion of fossil fuels has multimedia impacts which affect the air, land and water. Most conventional combustion processes emit oxides of sulfer $\left(\mathrm{SO}_{x}\right)$, oxides of nitrogen $\left(\mathrm{NO}_{x}\right)$, oxides of carbon, particular matter, and other potentially harmful pollutants 
to the air. The post-combustion solid residues of the fuel (e.g., ash material) pose solid waste disposal problems. Leaching of chemical compounds and heavy metals from the solid residues and transformation of airborne pollutants by rain may also result in adverse water-related health and ecological effects. To complicate matters, these effects are not separate and distinct; rather, they are all interrelated and involve delicate balances and trade-offs. Flue gas scrubbing to remove $\mathrm{SO}_{2}$ and particulates, for example, significantly increases the amount of solid wastes to be disposed of in an environmentally acceptable manner. In addition, there are many orders of indirect impacts that must be considered to understand fully the total impact on the environment. For example, the disposal of fly ash from coal-fired power plants has a direct impact on the land quality of the disposal sites. Leaching of chemical compounds and heavy metals from the disposal site has an indirect (second-order) impact on the quality of the ground and/or surface water. This in turn may have third-order impacts on the ecology of the area. Comprehensive identification and evaluation of these multimedia impacts, therefore, are essential to the environmentally wise use and control of conventional fossilfueled combustion processes.

The recognition of this need has resulted in a considerable amount of research by Government agencies and private organizations 
to identify and evaluate the adverse environmental impacts of conventional combustion processes and to develop methods of controlling such impacts.

The ERDA "Inventory of Federal Energy-Related Environment \& Safety Research for FY 1976" ${ }^{4}$--a limited inventory--1ists over 2500 R\&D projects for that year alone by 14 different agencies. Over a third of the total funding reported in the Inventory went directly for fossil fuel-related efforts. In addition to the Government, other organizations such as the Electric Power Research Institute, the American Gas Association, and the American Petroleum Institute also support millions of dollars worth of research in this area.

The Environmental Protection Agency (EPA), as the Federal organization with primary responsibility for controlling adverse environmental effects of pollutant emissions, has been active since its inception in determining the identities and quantities of potential pollutants released to the environment when fossil fuels are burned. Information from EPA R\&D efforts are being used for three principal purposes: to assess the health and environmental effects caused by the release of combustion pollutants to the environment; to define the needs for technology to control the release of these pollutants; and to develop standards to limit emissions. 


\section{B. Rationale for the Conventional Combustion Environmental Assess- ment (CCEA) Program}

Much of EPA's earlier work on characterizing pollutants from conventional combustion processes and assessing their effects on the environment was performed as an adjunct to programs whose major purpose was the development of control technologies for specific pollutants such as $\mathrm{NO}_{x}, \mathrm{SO}_{2}$, or solid wastes from combustion. In addition, studies by EPA and other organizations have generally had relatively specific objectives such as identifying emissions from a particular process, evaluating the effects of a particular compound, or developing technology to control a single pollutant. To date, however, few, if any, efforts have approached the environmental issue in a comprehensive, holistic manner. While data generated by past work have been important to developing an information base for conventional combustion processes, no studies have adequately addressed the identification and evaluation of the relationships that exist between second-order, third-order, and fourth-order environmental impacts; multipollutant synergistic impacts; and cross-media impacts. Furthermore, due to the very specific nature of study objectives and to the number of organizations involved in conducting such studies, coordination and information exchange between efforts has been relatively minimal. Even a cursory survey of past studies would reveal overlap and duplication of efforts in some areas and absence of significant effort in others. 
A. R\&D work in this area proliferates, it becomes necessary to cliannel these efforts into a systematic, coordinated, environmental assessment structure. A major integrated program must be undertaken now to tie together the separate data generated by past and ongoing Work and to complete a comprehensive environmental assessment of conventional combustion processes.

The methodology for developing such an integrated program must be carefully developed by a multidisciplinary group, understood by the R\&D community, and accepted by those involved in the coordinated effort.

C. The CCEA Program and Its Objectives

In response to the need for a conprehensive environmental assessment of conventional combustion systems, the Environmental Protection Agency's Industrial Environmental Research Laboratory at Research Triangle Park (EPA/IERL-RTP), North Carolina, is currently developing and implementing a unified Conventional Combustion Environmental Assessment (CCEA) program. It is a major new program aimed at the comprehensive assessment of environmental, economic, and energy impacts of multimedia pollutant emissions from stationary industrial, utility, residential, and commercial conventional combustion processes. The primary objective of the CCEA program is to identify and evaluate information from all relevant sources in order to: determine the extent to which this information can be utilized to assess the total 
environmental, economic, and energy impacts of conventional combustion processes; identify and acquire additional information needed for such assessment; define the requirements for modifications or additional development of control technology; and define the requirements for modified or new standards to regulate pollutant emissions.

The CCEA program will coordinate and integrate ongoing and future studies into a unified umbrella environmental assessment structure and serve as a centralized base of information on the environmental impacts of conventional combustion processes. Coordination and information exchange between CCEA-related studies should minimize duplication and maximize the return from available resources.

With the increasing concern over the health and ecological effects of energy conversion, coupled with the national goal of increased coal utilization, information and data developed from such an integrated effort will provide valuable inputs to technological and managerial decision-makers responsible for the continued and expanded use of conventional combustion processes at reasonable environnental, economic, and energy costs. 


\section{A COMPREHENSIVE ENVIRONMENTAL ASSESSMENT METHODOLOGY}

\section{A. Environmental Assessment Definition and Objectives}

The growing awareness of the range of direct and indirect environmental consequences of modern technology has given rise to new categories of investigative studies along with new terminology to describe these studies. Technology Assessments (TA's), Environmental Impact Statements (EIS's), Integrated Technology Assessments (ITA's), Environmental Assessments (EA's), etc. are being generated every year. Concise definitions of these terns, however, are quite difficult to find. This is especially true for an EA. Many studies are called environmental assessments when they are principally emission characterizations or a single pollutant impact identification.

EPA/IERL-RTP has developed a working definition of an environmental assessment that is becoming accepted by the research community. For EPA and its contractors, an environmental assessment of fossilfueled processes is defined as "a continuing iterative study aimed at:

"(1) determining comprehensive multimedia environmental loadings and environmental control costs, from the application of existing and best future definable sets of control/disposal options, to a particular set of sources, processes, or industries; and

"(2) comparing the nature of these loadings with existing standards, estimated multimedia environmental goals, 
and bioassay specifications as a basis for prioritization of problems/ control needs and for judgment of environmental effectiveness. ${ }^{5}$

An environmental assessment involves neither the development or promotion of the combustion process nor the development or promotion of technology to control emissions from the combustion process. It is a continuing process that is carried out simultaneously with technology development to identify and evaluate the full range of impacts (including cross-media impacts and trade-offs) of the combustion process and or control technology on the environment. The findings of an environmental assessment are aimed at providing a base of sound information for use by energy/ environmental decision-makers for:

- Standards Setting.

- Control Technology Development.

- Policy Formulation.

- Resource Allocation.

Outputs from a comprehensive environmental assessment would range from mere listings of pollutant emissions and descriptions of evaluation techniques, to identifications of quantified environmental impacts and to specific recommendations for decision-making. B. Functional Activities What, then, is the range of activities that must be undertaken in order to satisfy the objectives of a comprehensive environmental assessment? What are the input requirements for these activities, 
and what are the relationships between the activities? Where does one draw the boundaries for an environmental assessment?

EPA/IERL-RTP has been active for some time in answering the above questions and in developing a methodology to incorporate $E A$ components into its major programs. The environmental assessment methodology employed in the CCEA program draws heavily on the philosophies of the existing EPA/IERL-RTP methodology, but has been expanded and modified to be more responsive to the assessment of conventional combustion processes.

1. Generalized Environmental Assessment Methodology

In the most elementary of descriptions, an environmental assessment consists of three basic iterative steps. (See Figure 1.)

1. Characterization of the combustion process (including any associated pollution control devices) and its effluents.

2. Assessment of the health and ecological impacts of the combustion process and its effluents on the environment:

- Identification of environmental (health and ecological) impacts.

- Development of environmental goals and objectives.

- Comparison of impacts with environmental goals and objectives.

- Assessment of pollution impacts' magnitude.

3. Evaluation of alternative control strategies for use with the combustion process.

The first step in an environmental assessment is to characterize completely the combustion process in terms of a "black box" to identify all the pollutants emitted from the process, the quantities emitted, and the nature of the emissions (e.g., media involved, load distribution over time, and physical/chemical characteristics of the pollutants). 


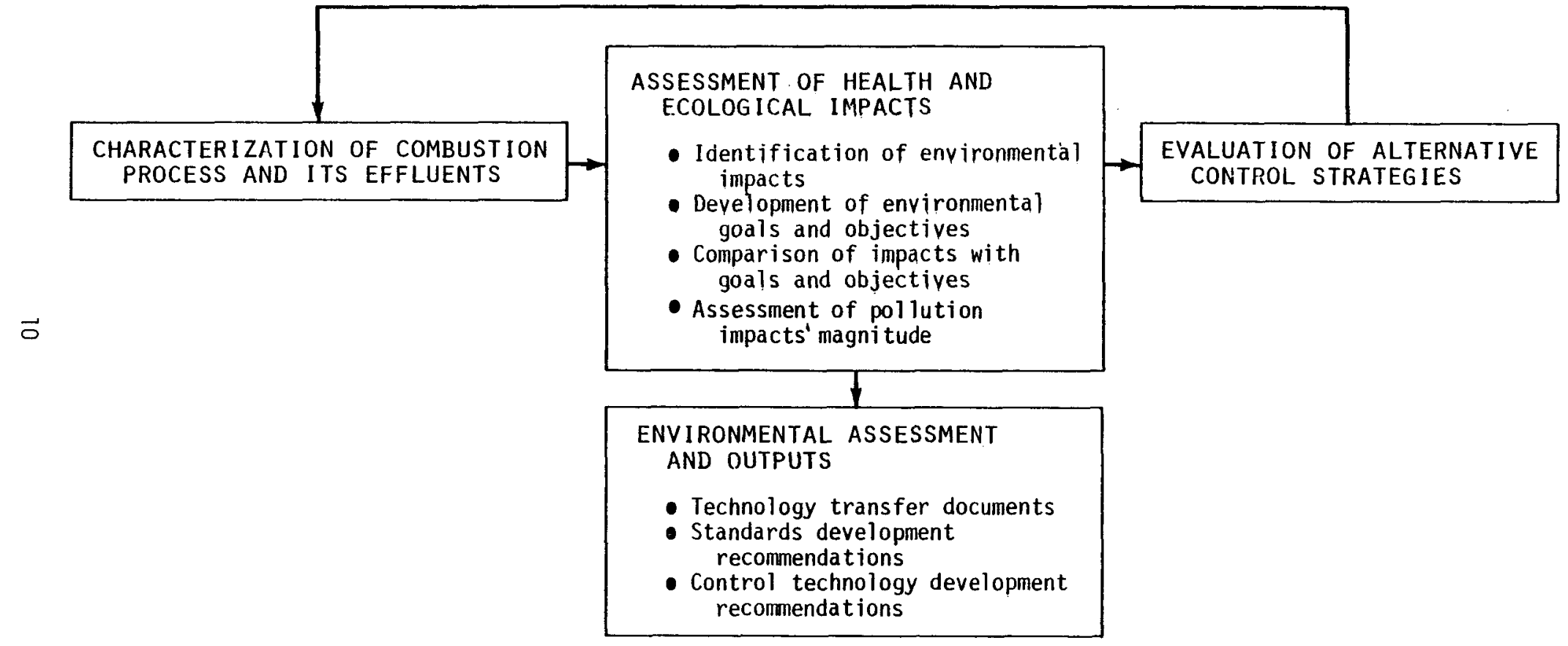

FIGURE 1

GENERALIZED ENVIRONMENTAL ASSESSMENT METHODOLOGY 
Once complete information on the effluents from the combustion process has been obtained, the second step of the environmental assessment is to determine the impacts of the process and its effluents on the environment. This process involves four general activities: (1) identification of the health and ecological impacts, (2) development of environmental goals and objectives, (3) comparison of the impacts with the goals and objectives to determine whether the impacts are acceptable, and (4) assessment of the pollution impacts' magnitude. If the results of activity three in this step indicate that the impacts of tile combustion process and its effluents on human health and the ecology are acceptable according to current environmental goals and objectives, then no problem is foreseen and the environmental assessment process has been completed. If, however, the results indicate that the impacts of the combustion process or its effluents are not acceptable according to current environmental goals and objectives, then the magnitude of the impacts must be assessed in activity four and ways to ameliorate these impacts must be identified.

The third step in an environmental assessment is to identify and evaluate alternative methods of reducing the deleterious environmental impacts and to select the optimum control strategy for use with the combustion process.

This entire procedure is repeated for the combination of the given combustion process and the control technology selected in step three, and for each combustion process considered by the environmental 
assessment. Technical reports are developed at every stage in the application of the environmental assessment methodology. Where impacts of the combustion process or its effluents on human health or ecology are serious, or where optimum existing control technologies are inadequate, specific recommendations for the promulgation of stricter environmental standards or for the development of additional control technologies are made for consideration by the appropriate decision-makers.

2. Detailed Environmental Assessment Methodology

A detailed environmental assessment methodology consists of various functional categories of information which interact to provide the desired data, information, or results.

As stated above, the first step in a comprehensive environmental assessment is the characterization of the combustion process and its effluents. Such a characterization comprises five functional categories of information:

- Process Technology Characteristics.

- Fuels Characterization.

- Input/Output Characterization.

- Development of Sampling and Analysis Tecinniques.

- Field Tests and Surveys.

Figure 2 shows the elements of each functional category and the relationship between the characterization of the combustion process effluents and the identification of the health and ecological impacts 


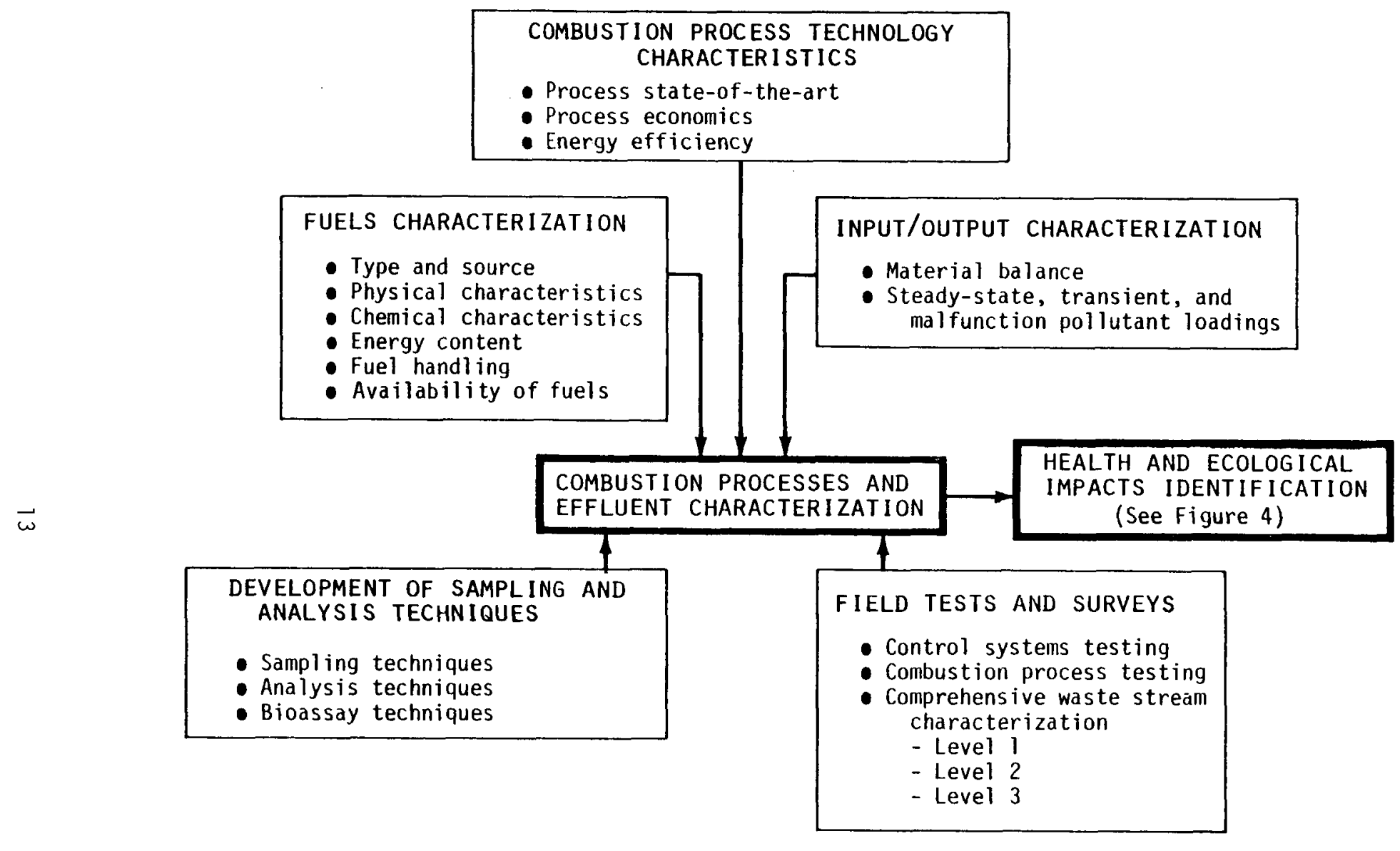

FIGURE 2

COMBUSTION PROCESSES AND EFFLUENT CHARACTERIZATION

(STEP ONE) 
activity of step two. Each functional category in this step is briefly described below.

Process Technology Characteristics is intended to provide detailed technical and operational information on the conventional combustion process. Information on the state-of-the-art of the combustion process including development status and commercial availability; process economics; energy efficiency; and reliability are considered in this functional category.

Fuels Characterization includes a description of the type and source of the fuel, physical and chemical characteristics including potential pollutants, energy content, fuel handling including methods of delivery and storage, and availability. Input/Output Characterization to establish the relationships among the process variables is an important environmental assessment functional category. Material balances for the combustion process and potential pollutant loadings for a variety of operating conditions such as steady-state, transient, and malfunction or other nonstandard states, should be developed.

Development of Sampling and Analysis Techniques (including bioassay techniques) are essential for assuring consistent and reliable results for comparison of data obtained by various investigators. Field Tests and Surveys using the standard sampling and analys is techniques are conducted to fully quantify and characterize the effluents. These tests and surveys are conducted on bench, pilot, demonstration, or full scale plants. EPA has established a detailed, 
phased screening, analysis, and monitoring protocol for various levels of waste stream characterizations. ${ }^{6}$ The three levels of characterization are:

Level 1 - Comprehensive Screening (including "Criteria Pollutants").

Level 2 - Directed Detailed Analysis based on Level 1 findings.

Lever 3 - Process Monitoring on Selected Priority Pollutants based on Level 1 and Level 2 findings.

The second step in an EA, the assessment of the health and ecological impacts of the combustion process and its effluents, is shown in Figure 3. The assessment of health and ecological impacts involves four general activities.

1) Identification of the health and ecological impacts of the combustion process and its effluents.

2) Development of environmental goals and objectives.

3) Comparison of the impacts with the environmental goals and objectives.

4) Magnitude of pollution impacts.

The identification of the nealth and ecological impacts of the combustion process (including any associated control technology) is the first activity of the second step. It includes detailed analysis of the response of the environment and the exposed population's health to the pollutant loadings of the process. This includes data collection and analysis relating to the air, water and 1 and 


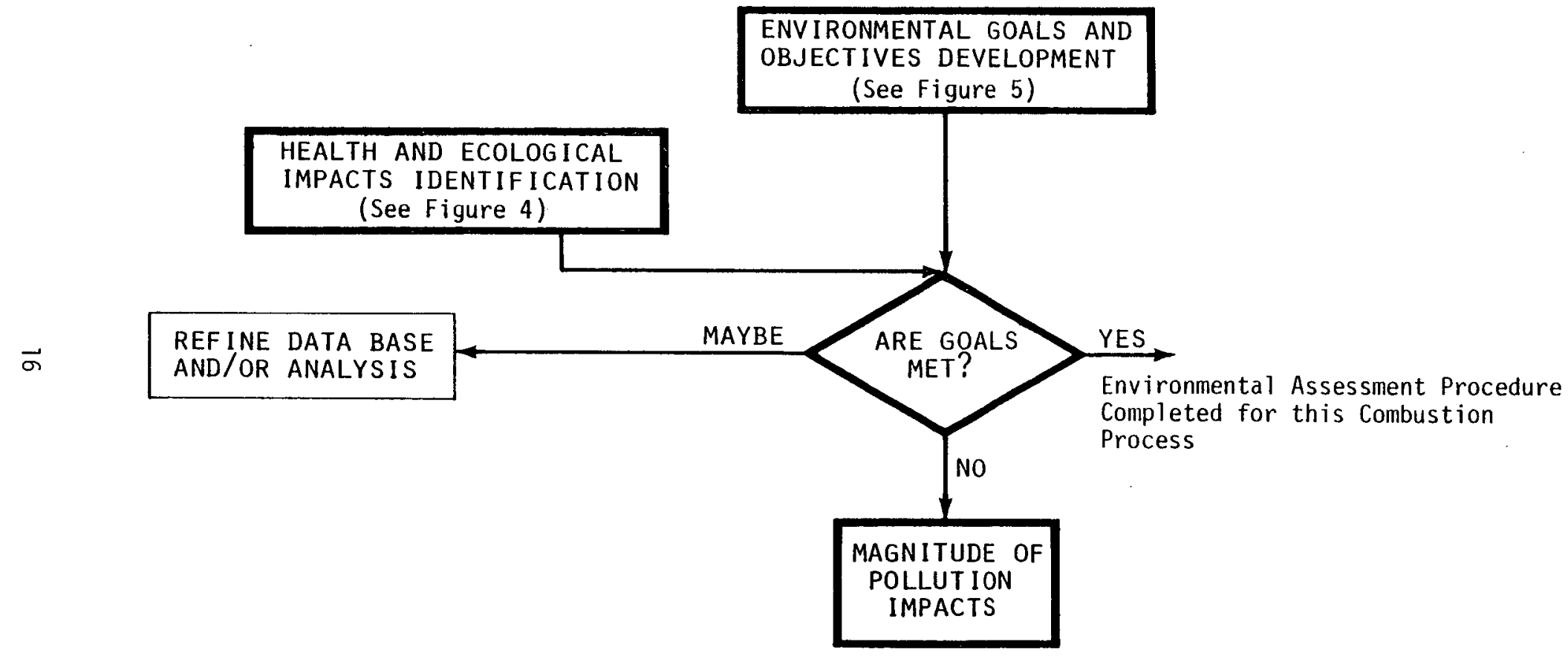

FIGURE 3

ASSESSMENT OF HEALTH AND ECOLOGICAL IMPACTS (STEP TWO) 
quality, ecology-related effects, increased morbidity and mortality rates, and quantified media degradation alternatives.

Combustion process and effluent characterization (the first step), previously discussed, serves as an input to health and ecological impacts identification as shown in Figure 4 . Additional inputs to this activity are provided by the following functional categories:

- Ecological Impacts.

- Dose-Response Data.

- Pollutant Transport, Transformation, and Fate Models.

- Bioassay Data.

- Epidemiological Data.

Ecological Impacts identification is necessary to evaluate relevant information to quantify such concepts as media degradation. Dose-Response Data allow the translation of pollution concentrations in the environment into an estimate of the number and type of specific biological impacts to be expected in an exposed population. Doseresponse data relate exposure concentration and exposure time to the probability of observing a given biological response. Thus the exposure to a given $\mathrm{SO}_{2}$ concentration for 3 hours may be expected to result in a certain number of cases of respiratory ailments, or a given average annual $\mathrm{SO}_{2}$ concentration may result in an estimate of increased mortality. In addition to available dose-response data such as threshold limit values (TLV) and lethal concentration for 50 percent mortality in the exposed population ( $L C 50$ ), information in terms 
DOSE-RESPONSE DATA

- Thresnold limit values (TLV)

- Life-shortening chronic exposure

- Cancer and leukemia

- Respiratory disease

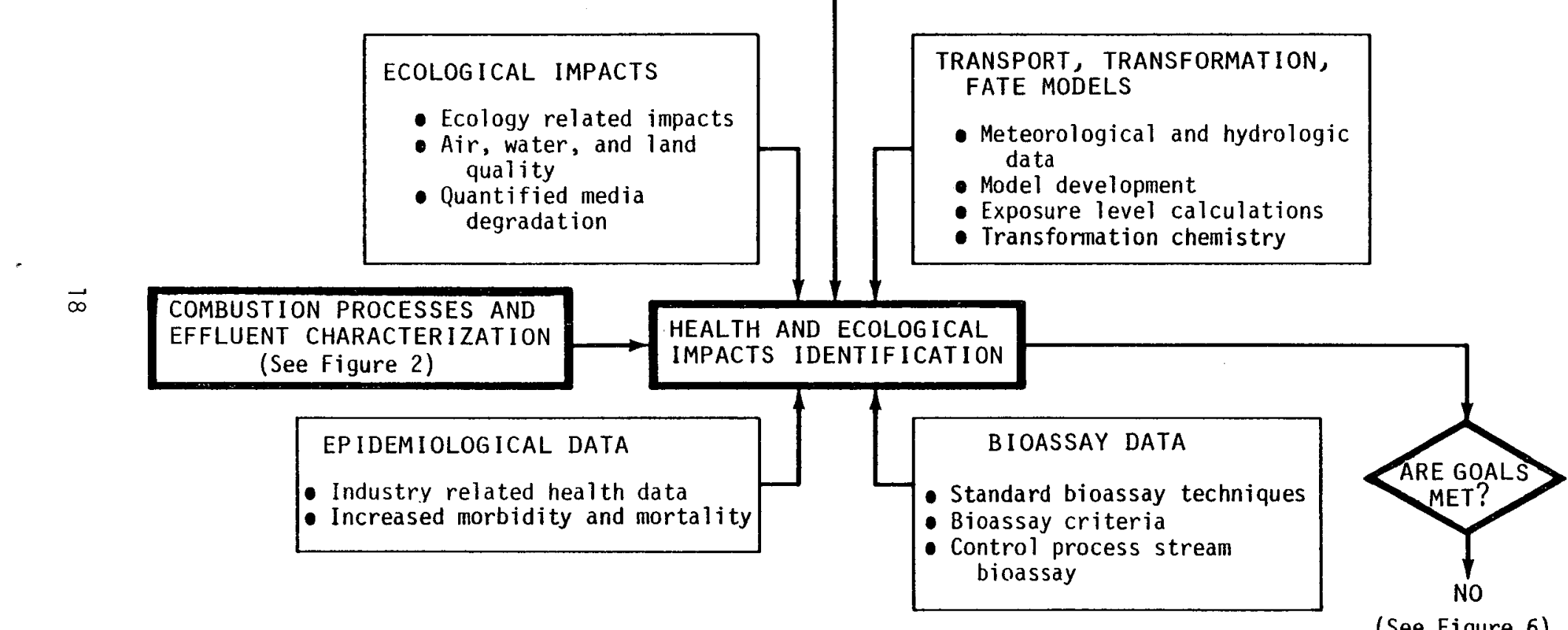

FIGURE 4

HEALTH AND ECOLOGICAL IMPACTS IDENTIFICATION

(FIRST ACTIVITY, STEP TWO) 
of cancer, leukemia, respiratory disease, or other chronic or acute responses is often important in identifying the health and ecological impacts of the combustion process and its effluents. Pollutant Transport, Transformation, and Fate Models are used in calculating pollutant concentrations and exposure levels. Meteorological and hydrological data, and pollutant chemical transformation and reactivity data must be developed for use in the models. Bioassay Data identifying the effects of varying concentrations of pollutants on living organisms serve to augment dose-response data. Included among the bioassays of interest are those relating to health and ecological effects. Health effects-related bioassays include:

- Microbial bioassays (e.g., Salmonella typhimurium bacterial mutagenicity screening test).

- In vitro bioassays (e.g., alveolar macropnage cytotoxicity tests, epithelial cell carcinogenicity screen).

- In vivo bioassays (e.g., mammalian toxicity tests, carcinogenicity screen).

Ecological effects-related bioassays include:

- Laboratory studies on single/multiple plant or animal species (e.g., acute toxicity studies, carcinogenicity screening tests).

- Microcosm studies of terrestrial, marine, or aquatic communities.

- Field studies of ecosystems.

Epidemiological Data developed from occupational exposure-related health information are important indicators of potential adverse pollutant impacts. Examination of vital statistics and data on 
specific $i 17 n e s s e s$ and diseases in exposed populations may allow identification of the specific agent responsible or alert investigators to the possibility of such effects being associated with a particular process.

The second activity in the assessment of the health and ecological impacts (second step) is the development of environmental goals and objectives. These environmental goals and objectives are developed as standards or indices of acceptability. These indices of acceptability are based on a variety of interrelated factors including health effects, ecological effects, physical effects, socio-economics, and institutional/political and legals constraints. These environmental goals and objectives may be expressed in such terms as process/pollutant emission rates, ambient pollutant concentrations in the various media, or environmental nondegradation criteria. As snown in Figure 5, the four major functional categories to be addressed in developing the environmental goals and objectives include:

- Statutory Constraints.

- Emission or Ambient Level Goals.

- Social/Economic/Political/Institutional Considerations.

- Ambient Pollutant Levels. 


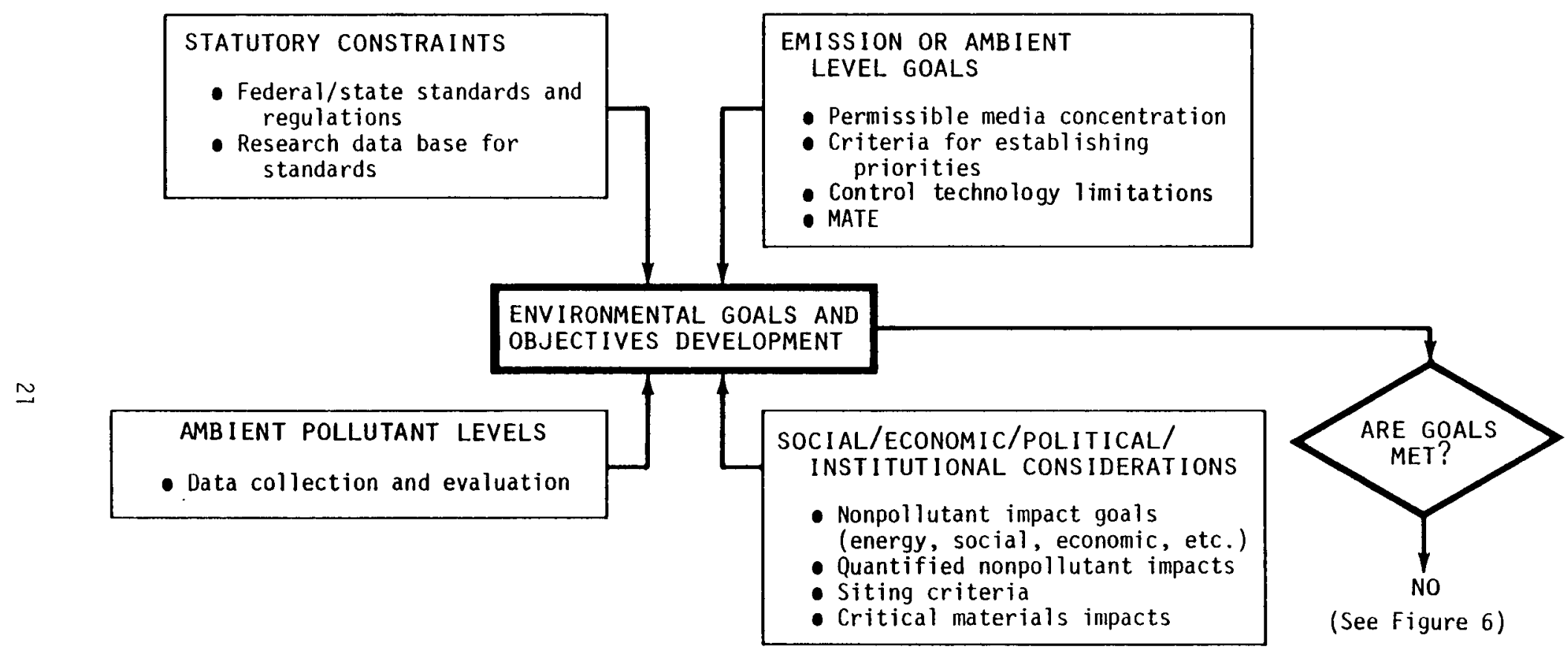

FIGURE 5

DEVELOPMENT OF ENVIRONMENTAL GOALS AND OBJECTIVES

(SECOND ACTIVITY, STEP TWO) 
Statutory Constraints considered in developing environmental goals and objectives include:

- National Primary and Secondary Ambient Air Quality Standards.

- State Implementation Codes.

- OSHA Standards for Air Contaminants.

- National Emission Standards for Hazardous Air Pollutants.

- New Stationary Source Performance Standards.

- National Interim Primary Drinking Water Regulations.

- EPA Effluent Standards.

- EPA Toxic Pollutant Effluent Standards (proposed).

- EPA Pesticide Limits.

- Criteria for the Evaluation of Permit Applications for Ocean Dumping of Materials.

Emission or Ambient Level Goals for each of the applicable air, water or land media may be based on control technology capabilities or on ambient factors. Goals based on control technology capabilities consider performance data on Best Available Technology (BAT), Best Practicable Technology (BPT), or engineering estimates for developing technologies to establish pollutant emission level indices. Goals based on ambient factors are dependent on the health or ecological effects of the pollutant. Factors considered in establishing ambient level goals include such parameters as Minimum Acute Toxicity Effluent (MATE), and health and ecological toxicity based on estimated permissible concentrations. 
Social/Economic/Political/Institutional Considerations in developing environmental goals and objectives include a variety of quantitative and qualitative factors such as the impact of the combustion process on 1 and use and degradation, water use, and other factors including energy use patterns, social/cultural patterns, regional and National economy, aesthetics, siting criteria, and critical materials impacts. Ambient Pollutant Levels must be considered in setting such environmental goals as "no significant deterioration" (elimination of discharge based on not exceeding natural background levels). This can best be achieved through extensive data collection and evaluation. EPA/IERL-RTP has established a format for evaluating the information in each of the functional categories discussed above in order to develop measures of acceptability for each pollutant. These measures of acceptability, called Multimedia Environmental Goals (MEG's), are similar to the Emission or Ambient Level Goals described earlier, but include consideration of the other three functional categories. An example of a MEG for the compound 2-aminonaphthalene is shown in Table 1. Table 2 shows a background information sheet summarizing al 1 pertinent information used in developing the MEG for the compound. Currently, approximately 350 organic and 300 inorganic substances are on the MEG list. 
TABLE 1

SAMPLE MEG CHART $^{7}$

\section{MULTIMEDIA} ENVIRONMENTAL GOALS

2.MMINONAPHTHA

\begin{tabular}{|c|c|c|c|c|c|c|c|}
\hline \multirow{2}{*}{\multicolumn{8}{|c|}{ EMISSION LEVEL GOALS }} \\
\hline & & & & & & & \\
\hline \multirow[b]{4}{*}{$\begin{array}{l}\text { Air, } \mu \mathrm{g} / \mathrm{m}^{3} \\
(\mathrm{ppm} \mathrm{Vol})\end{array}$} & \multicolumn{2}{|c|}{ 1. Based on Best Technology } & \multicolumn{5}{|c|}{ 11. Based on Ambient Factorn } \\
\hline & A. Existing Stundards & \multirow{2}{*}{ 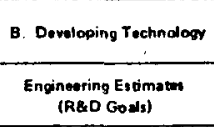 } & \multicolumn{2}{|c|}{$\begin{array}{l}\text { A. Minimum Arute } \\
\text { Toxicin Ettluente }\end{array}$} & \multicolumn{2}{|c|}{ B. Ambiren Level Goas" } & \multirow{2}{*}{ 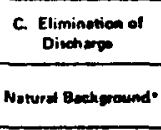 } \\
\hline & NSPS, BPT, BAT & & $\begin{array}{c}\text { Bmod on } \\
\text { Hods Eth EHoct }\end{array}$ & $\begin{array}{l}\text { Based on } \\
\text { Ecological } \\
\text { Effioess }\end{array}$ & $\begin{array}{l}\text { Based on } \\
\text { Healt EHecs }\end{array}$ & $\begin{array}{l}\text { Benod on } \\
\text { Eecolopices } \\
\text { E Hocs }\end{array}$ & \\
\hline & & & $1.65 \mathrm{E} 2$ & & 0.4 & & \\
\hline 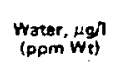 & & & $2.5 \mathrm{E} 3$ & 1. OE2 & 6 & 50 & \\
\hline $\begin{array}{l}\text { Land, } \mu \mathrm{g} / \mathrm{g} \\
\text { (ppon Wr) }\end{array}$ & & & 5. OEO & 2. $0 E-1$ & 0.012 & 0.1 & \\
\hline
\end{tabular}

- To be multiplied by dilution factor

\begin{tabular}{|c|c|c|c|c|c|}
\hline \multicolumn{6}{|c|}{ AMBIENT LEVEL GOALS } \\
\hline & \multicolumn{2}{|c|}{$\begin{array}{l}\text { 1. Current or Proposed Ambient } \\
\text { Standards or Criteria }\end{array}$} & \multicolumn{2}{|c|}{$\begin{array}{l}\text { II. Toxicity Based Estimated } \\
\text { Permissiblo Concentration }\end{array}$} & \multirow{2}{*}{ 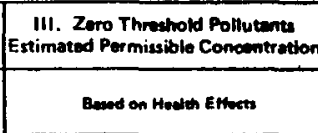 } \\
\hline & $\begin{array}{l}\text { A. Bond on } \\
\text { Heat in Eftiects }\end{array}$ & $\begin{array}{l}\text { A. Eaved on } \\
\text { Ecological Eftects }\end{array}$ & $\begin{array}{l}\text { A. Busod on } \\
\text { Mealts Eifoett }\end{array}$ & $\begin{array}{l}\text { A. Ansed on } \\
\text { Ecolopient Efroet }\end{array}$ & \\
\hline $\begin{array}{l}\text { Ait, } \mu \mathrm{g} / \mathrm{m} \\
\text { (pom Vol) }\end{array}$ & & & 59 & & 0.4 \\
\hline $\begin{array}{l}\text { Watser, } \mu g / 1) \\
\text { (ppm wt) }\end{array}$ & & & 291 & 50 & 6 \\
\hline $\begin{array}{l}\text { Land, } \mu g / g \\
\text { (ppm } W t)\end{array}$ & & & 0.6 & 0.1 & 0.012 \\
\hline
\end{tabular}


TABLE 2

SAMPLE MEG BACKGROUND INFORMATION SHEET ${ }^{7}$

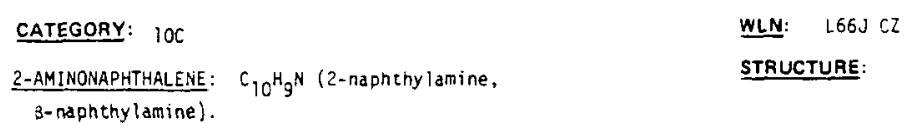

White crystals that darken on exposure to light and air; volatile with steam.

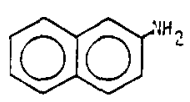

PROPERTIES:

Molecular wt: $343.19 ; \mathrm{mp}: 113 ; \mathrm{bp}: 306 ; \mathrm{d}: 1.0614_{4}^{98}$; vap. press.: $1 \mathrm{~mm}$

at $108^{\circ} \mathrm{C}$; volatile in steam; slightly soluble in cold water.

\section{NATURAL OCCURRENCE, CHARACTERISTICS, ASSOCIATEO COMPOUNDS:}

2-Naphthylamine does not occur as such in nature, but is formed by the pyrolis is of nitrogen-containing organic matter. It has been isolated from codi-tar (ref. 44). It has, in general, the characteristics of primary aromatic amines. It is a weak base.

\section{TOXIC PROPERTIES, HEALTH EFFECTS:}

Epidemiological studies have shown that occupational exposure to 2-aminonaphthalene is strongly associated with the occurrence of bladder cancer. There is no doubt that the compound is a human bladder carcinogen (ref. 44). 2-Aminonaphthalene is aiso reported to cause cancer in several animal species.

The EPA/NIOSH ordering number is 7628 . The lowest dose to induce a carcinogenic response is reported as $18 \mathrm{mg} / \mathrm{kg}$. The adjus ted ordering number is 423.8 .

$L_{50}$ (oral, rat): $727 \mathrm{mg} / \mathrm{kg}$.

Aquatic toxicity: TLm 96: 10-1 ppm (ref. 2).

REGULATORY ACTIONS, STANDARDS, CRITERIA, RECOGNITION, CANDIDATE STATUS FOR SPECIFIC REGULATION

2-Aminonaphthalene is recognized by ACGIH as a carcinogenic agent in humans. No TLV has been assigned. B-Naphthylamine was the subject of a MIOSH Hazard Review Document (ref. 43).

OSHA standards dealing with exposure of employees to 2-naphthylamine has been established taking into consideration substantial evidence that 2-naphthylamine is known to cause cancer (ref. 17).

\section{MINIMUM ACUTE TOXICITY CONCENTRATIONS}

Air, Health: $7 \times 10^{4} / 423.8=165 \mathrm{ng} / \mathrm{m}^{3}$ Water, Health: $15 \times 165=2.5 \times 10^{3} \mathrm{ug} / 2$

Land, Health: $0.002 \times 2.5 \times 10^{3}=5 ; \mathrm{sg} / \mathrm{g}$

\section{ESTIMATED PERMISSIBLE CONCENTRATIONS}

Air, Ecology:

Water, Ecology: $100 \times 1=i 00 \mathrm{ug} / \ell$

Land, Ecology: $0.002 \times 100=0.2 \mathrm{wg} / \mathrm{g}$

\footnotetext{
$E_{\text {EPC }}=0.107 \times 727=78 \mathrm{ug} / \mathrm{m}^{3}$

$E E_{A H 3}=0.081 \times 727=59 \mathrm{\mu g} / \mathrm{m}^{3}$

$E P C_{W H 1}=15 \times 59=3,500 \mathrm{vg} / \mathrm{R}$

$E P C_{W H 2}=0.4 \times 727=291 \mathrm{\mu g} / \mathrm{s}$

$E P C_{L H}=0.002 \times 291=0.6 \mu 9 / 9$

$E P C_{A C 2}=10^{3} /(6 \times 423.8)=0.4 ; \mathrm{gg} / \mathrm{m}^{3}$

$E P C_{W C}=15 \times 0.4=6 \mathrm{~kg} / z$

$E P C_{I C}=0.002 \times 6=0.012 \% g / 9$
}

$$
\begin{aligned}
& E P C_{W E 1}=50 \times 1=50 \mathrm{ug} / 2 \\
& E P C_{L E}=0.002 \times 50=0.129 / 9
\end{aligned}
$$


The third activity in step two is the comparison of the hearth and ecological impacts identified earlier with the goals and objectives developed above. If all the health and ecological impacts are acceptable by current goals and objectives, then the EA process is finished. If there is any question about the acceptability of the impacts due to insufficient or unreliable data, a data refinement and re-evaluation interaction may be necessary to draw final conclusions. If, on the other hand, the impacts of the combustion process and its effluents are unacceptable according to current environmental goals and objectives, then the magnitude of these impacts must be assessed and methods to ameliorate or control them must be identified.

The assessment of the magnitude of those pollution impacts not considered acceptable according to the goals and objectives is the fourth activity in step two (the assessment of health and ecological impacts). The major functional categories in this activity include:

- Combustion Process Use Projections.

- Synergistic and Multimedia Impacts

- Total Pollutant Load Calculations.

- Regional Geographic Data.

- Pollutant Priority Ranking.

These functional categories and their elements are shown in Figure 6. Combustion Process Use Projections are used to determine the number and distribution of the combustion process in use both now and in the future (to the year 2000). Factors considered in this functional 


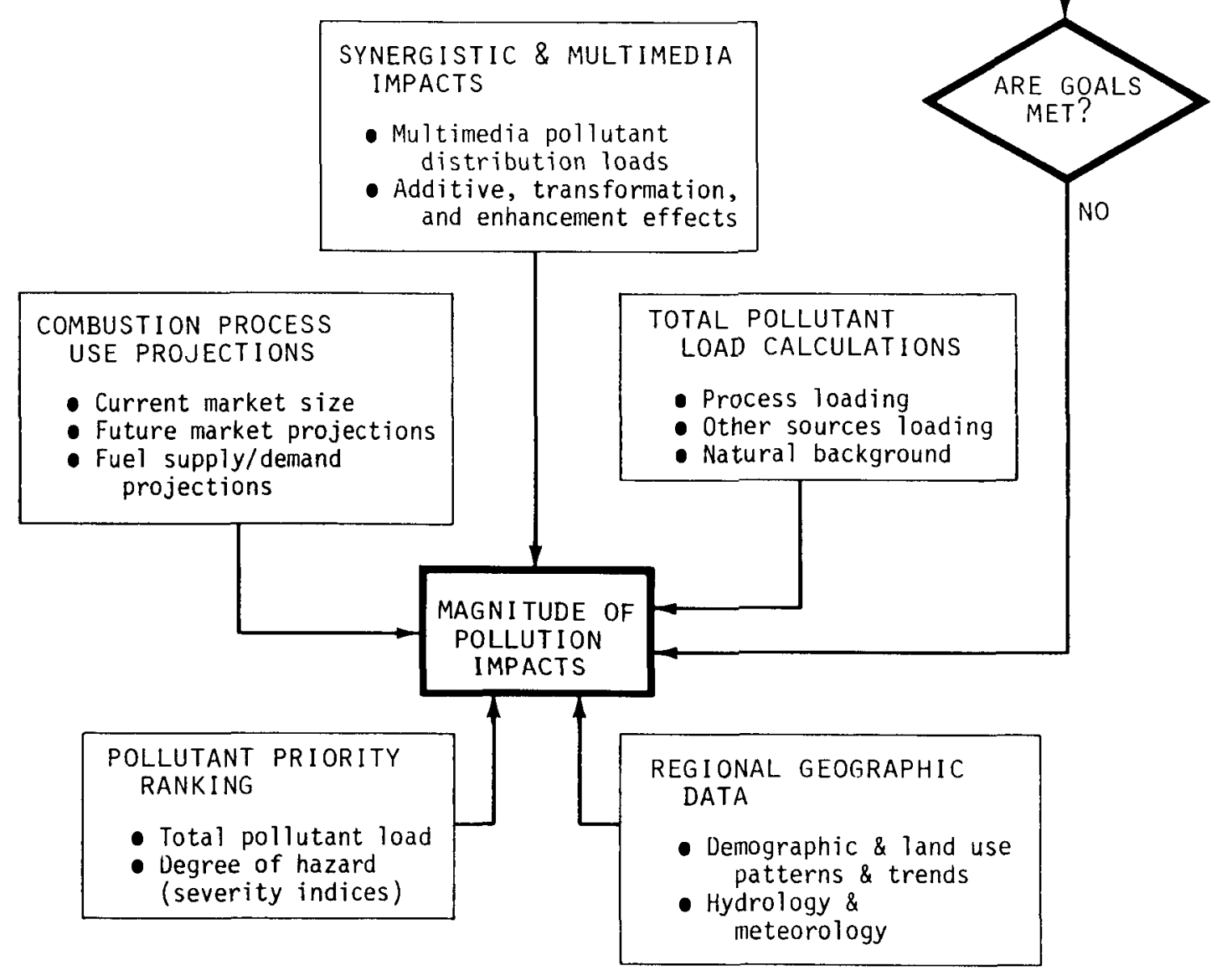

F IGURE 6

MAGNITUDE OF POLLUTION IMPACTS

(FOURTH ACTIVITY, STEP TWO) 
category include current and projected market size, and fuel supply/ demand projections. Information developed in this functional category is used for total pollutant load calculations. Synergistic and Multimedia Impacts are key considerations in comprehensive quantification of pollution impacts. For example, $\mathrm{SO}_{2}$ emitted to the atmosphere may react with water to form acid and pollute surface and groundwater systems. Another multimedia effect is the leaching of heavy metals from solid waste disposal sites. Synergistic impacts such as the additive, transformation, or enhancement effects of two or more pollutants are also included in this functional category. Total Pollutant Load Calculations are based on three types of information: (1) process loading, (2) loading from other sources, and (3) natural background loading. Total process loading is calculated in simple terms by multiplying the pollutant load from each combustion process by estimates of tine number of such processes (determined in the process use projections functional category). Similarly, pollutant loadings from other conventional and nonconventional combustion sources must be determined to calculate the total pollutant loading from all combustion sources. In addition, natural background loading from nonmanmade sources must be determined in calculating the total pollutant load to the environment. 
Regional Geographic Data important in quantifying the environmental impacts include regional population growth projections, and local hydrology and meteorology. These data evaluated in terms of the regional total pollutant load and health effects data should form the basis of environmental impacts quantification.

Pollutant Priority Ranking is then developed using the above data and degree of hazard calculations (severity indices). This ranking is useful in identifying standards or pollution control needs. Standards Development Recommendations result when impacts of the combustion process or its effluents on human health or ecology are serious and no Government standards exist to control these impacts. The identification of a need for modification or development of new standards is one of the major outputs of comprehensive environmental assessment. Recommendations for stricter (or more lax) standards should be ranked in order of priority and should be justified by specific data. Information on the degree of control desired and a time-frame for promulgation would accompany such reconmendations.

The third step in a comprehensive environmental assessment, Alternative Control Strategy Evaluation, is heavily dependent on the results of the first two steps. As shown in Figure 7 , the identification, evaluation, and selection of optimum alternative strategies or technologies to control unacceptable environmental impacts of the combustion process or its effluents include functional categories of information on: 


CONTROL TECHNOLOGY DEVELOPMENT
RECOMMENDATIONS
- Control technology
modifications
- Quantified R\&D needs
Criteria for priorities
Time frame

CONTROL STRATEGY ENVIRONMENTAL
IMPACTS
- Waste disposal options
- Secondary environmental
impacts
- Cross-media impacts

environmental

impacts

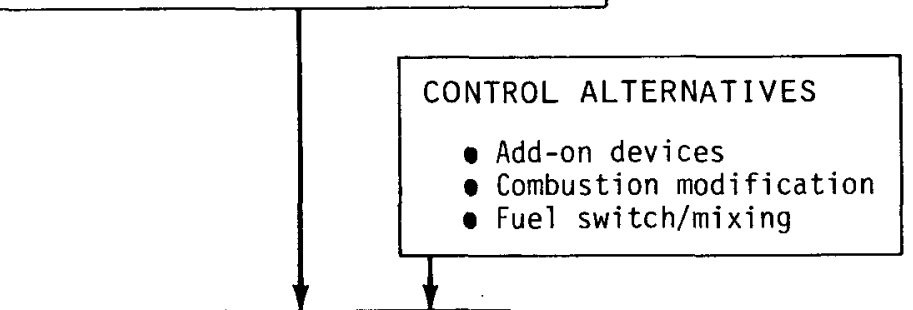

ALTERNATIVE CONTROL

STRATEGY EVALUATI ON

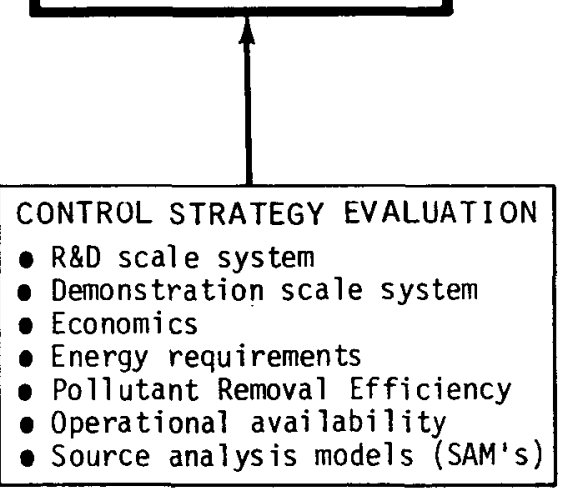

STANDARDS DEVELOPMENT RECOMMENDAT IONS

- Standards modifications

- Standards development

- Criteria for priorities

- Time frame

FIGURE 7

ALTERNATIVE CONTROL STRATEGY EVALUATION

(STEP THREE) 
- Control Alternatives.

- Control Strategy Environmental Impacts.

- Control Strategy Evaluation.

Control Alternatives addressing unacceptable pollutant impacts are identified based on existing technologies or on developmental technologies expected to become available in the near future. Alternatives considered include not only add-on control systems, but also such strategies as combustion modification or fuel switching/mixing. A11 reasonable alternatives are identified in this functional category for further evaluation and selection.

Control Strategy Environmental Impacts must be considered in order to assess any secondary environmental problems associated with the operation of the control system itself. This is necessary since many control systems emit substance(s) particular to their operation while others produce wastes (such as ash or sludge) as by-products of their operation. Options for the environmentally acceptable disposal of these wastes are also identified and evaluated in this category. Cross-media impacts are also important el ements to consider in evaluating the environmental impacts of the control system. For example, while flue gas desulfurization (FGD) reduces gaseous pollutant emissions, it has a cross-media impact by increasing liquid and solid pollutants that require environmental control. 
Control Strategy Evaluation is aimed at determining the optimum pollution control alternative for the particular pollutant, effluent/emission stream, or combustion process. This evaluation could be applied to both R\&D scale emerging control technology or to demonstration-scale or fully commercialized systems. In addition to the pollutant removal efficiencies and operational availabilities of the systems, economics (including by-product disposal cost) must also be considered. Information on energy penalties imposed by the control strategy, the specific fuel mix availability, and industry acceptance of the strategy are also included in this functional category. In general, this evaluation is site-specific since ambient concentration levels and local meteorology and hydrology are important factors. EPA has developed a set of Source Analysis Models (SAM's) ${ }^{6}$ to rank sources and effluents in priority order and to evaluate the environmental effectiveness of control alternatives. Three sets of SAM's have been developed to date:

SAM/IA --- For Rapid Screening.

SAM/ I --- For Screening.

SAM/II --- General Approach to Evaluating Any U.S. RegionaT Site.

Control Technology Development Recommendations are logically made when existing or developmental alternatives for controlling adverse environmental impacts are inadequate. The recommendations for additional control technologies are among the most important outputs of an environmental assessment. These recommendations should be 
quantified and ranked in priority order for technological and managerial decision-makers. The priority recommendations should be justified on engineering and environmental bases, and should include information on degrees of control required, additional $R \& D$ requirements, developmental cost estimates, and projected developmental schedules.

When optimum alternatives to control unacceptable environmental impacts are selected, they are applied to the original combustion process and the entire environmental assessment procedure is repeated for the combination of the combustion process and the control technology alternative. The complex, interactive and iterative nature of an environmental assessment is illustrated more clearly by combining each of the various steps and activities shown in Figures 1 through 7 into the detailed EA methodology diagram shown in Figure 8. Ideally, the iterative methodology of Figure 8 is continued until all impact on human health and ecology caused by the combustion process falls within acceptable limits of current environmental goals and objectives. 


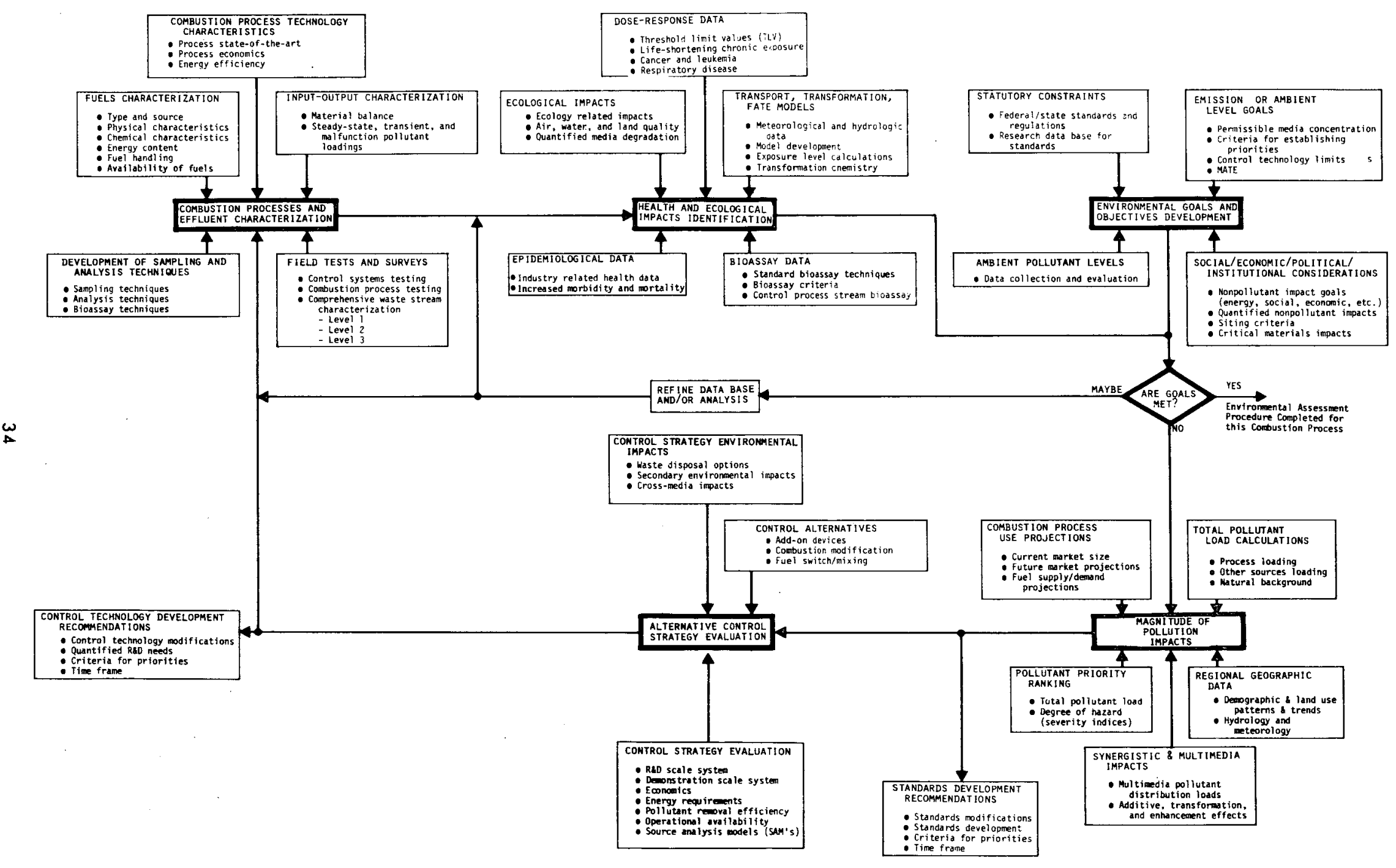


III. CCEA PROGRAM PLANNING

The preceding section described in general terms the methodology for conducting a comprehensive environmental assessment of any set of combustion sources, processes, or industries. The CCEA program employs this methodology to conduct a comprehensive environmental assessment of stationary, conventional combustion processes.

A. Overall Planning Technique

As a part of the evolution of techniques for environmental R\&D program planning, MITRE/Metrek (under contract to EPA) has developed a conceptual pattern characterizing the functional steps involved in such efforts. This conceptual pattern has been tailored to the specific CCEA program planning effort and is illustrated in Figures $9 A$ and $9 B$.

This overall approach is divided into eight distinct tasks as indicated diagrammatically in Figures $9 \mathrm{~A}$ and $9 \mathrm{~B}$ and listed below:

1. Review of Existing EPA/IERL-RTP CCEA Projects.

2. Identification and Evaluation of Related Projects by Other Organizations.

3. Disaggregation by Relevant Activities of Existing Projects into Environmental Assessment Functional Categories.

4. Structured Aggregation of Relevant Project Activities. Within Environmental Assessment Functional Categories.

5. Current Environmental Information Base.

6. Development of Goals and Objectives for Unified CCEA Program.

7. Evaluation of Integrated Existing CCEA Program.

8. Development of Unified CCEA Program Plan. 


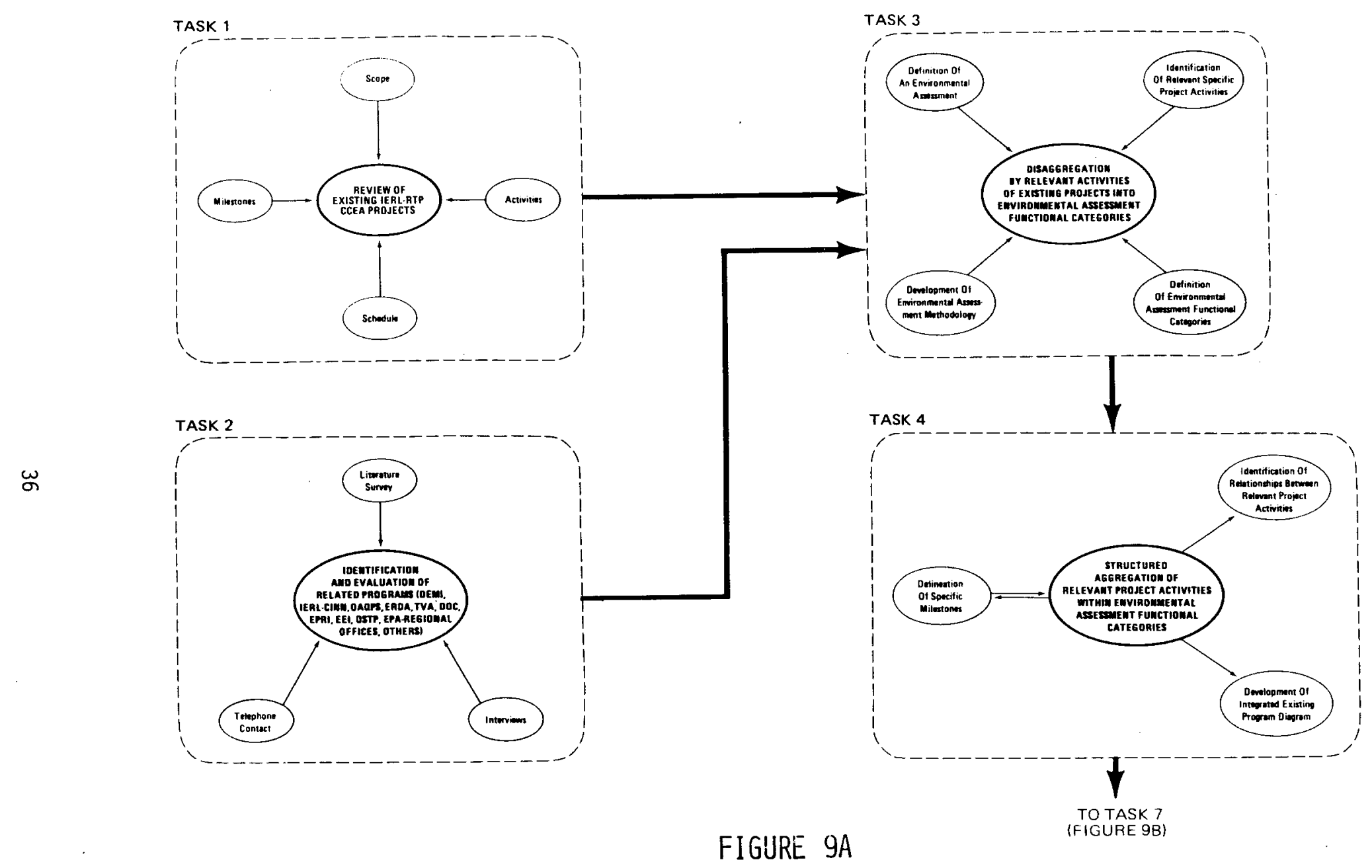

UNIFIED CONVENTIONAL COIIBUSTION ENVIRONMENTAL ASSESSMENT PROGRAIN PLANNING 


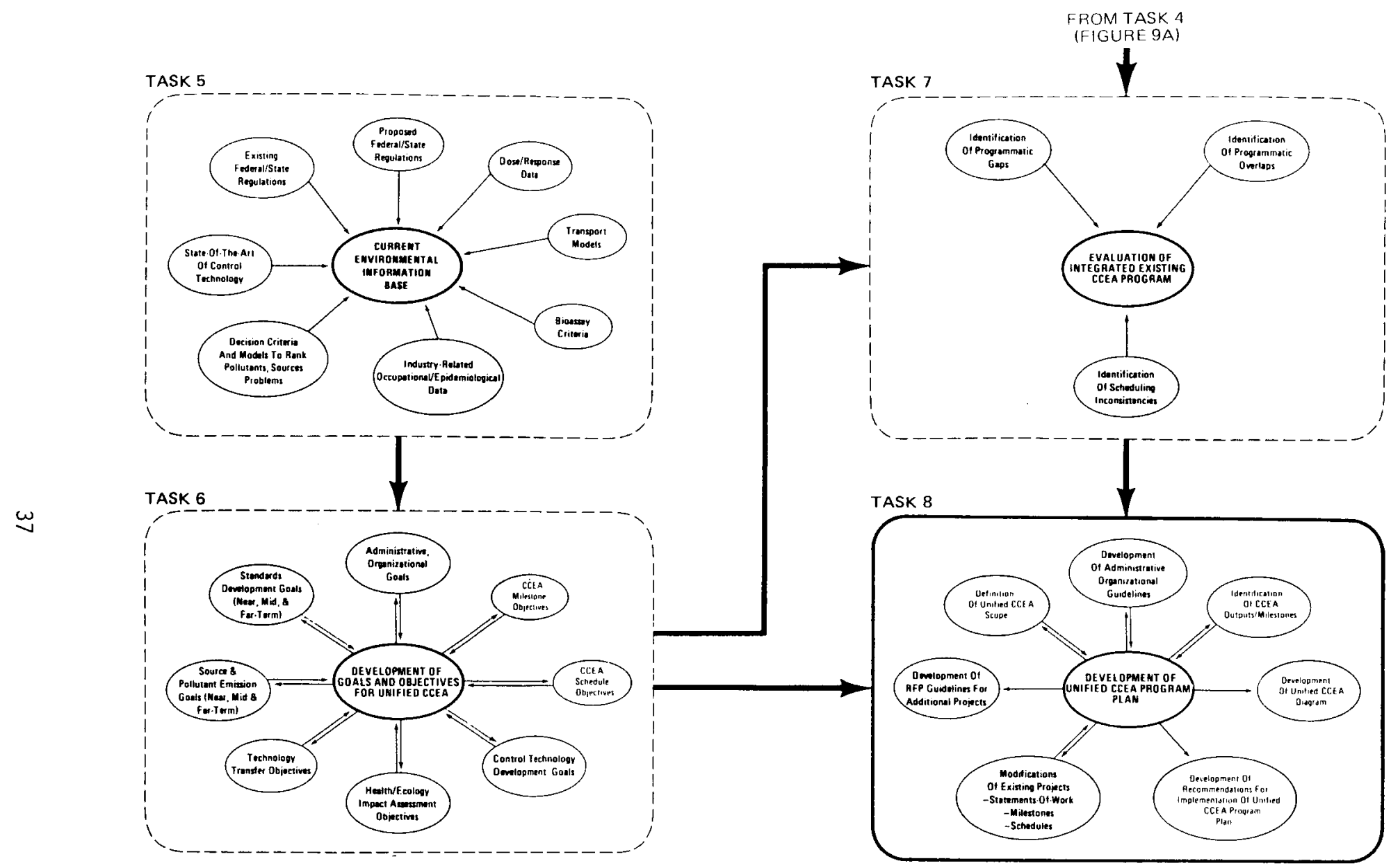

FIGURE 9B

UNIFIED CONVENTIONAL COMBUSTION ElNVIRONMENTAL ASSESSINENT PROGRAM PLAiNINING 
Task 1 involved the review of ongoing CCEA-related projects at EPA/IERL-RTP to identify their specific objectives, activities, milestones, and schedules. Simultaneous with Task 1, Task 2 identified, acquired, and reviewed information on past and ongoing combustion assessment-related projects outside of EPA/IERL-RTP to determine possible informational/program links with CCEA. Organizations surveyed within EPA included: Office of Energy, Minerals, and Industry (OEMI); IERL. at Cincinnati; Office of Air Quality Planning and Standards (OAQPS); and EPA Regional Offices. Organizations surveyed outside of EPA included: Department of Energy (DOE) (Energy Research and Development Adninistration [ERDA]); Electric Power Research Institute (EPRI); Tennessee Valley Authority (TVA); Edison Electric Institute (EEI); Department of Commerce (DOC); Office of Science, Technology, and Policy (OSTP); Department of Agriculture (DOA); Department of Health, Education, and Welfare (HEW); and the National Science Foundation (NSF).

The information identified in Tasks 1 and 2 as being relevant to the unified CCEA was analyzed in Subtask 3, where specific activities of the relevant projects were disaggregated into generic environnental assessment functional categories. Activities addressing similar subjects or involving similar efforts in the various combustion assessment-related efforts were separated for comparative evaluation to be carried out in Task 4, where these activities were aggregated (or integrated) into a logical environmental assessment 
structure. By such structured integration, the basic characteristics of the unified CCEA could be delineated and the relationships between the activities of the various programs could be identified.

Concurrent with the integration of relevant projects into environmental assessment functional categories, two independent tasks were conducted to develop the goals and objectives of the expanded unified CCEA. In Task 5, an information base of the current environmental background was established. The information base included data on existing and proposed environmental regulations, heal th/ecology impacts, state-of-the-art of associated control technologies, and environmental modeling. This information was analyzed and utilized in Task 6 to develop the goals and objectives of the expanded, unified CCEA program. Goals and objectives for standards, control technology development, and technology transfer were formulated. Administrative and organizational goals for the implementation of the unified CCEA program plan were also developed in Task 6 .

The existing combustion assessment related activities, integrated into functional categories in Task 4, were evaluated in Task 7 with respect to the newly developed unified CCEA goals and objectives. By such a comparative evaluation, programmatic gaps within the existing structure could be identified. Programmatic overlaps among the various existing programs as well as possible incompatibilities in scheduling could also be identified within this Task. 
The results of this comparative evaluation were matched in Task 8 with the goals and objectives for the CCEA in order to develop a coherent and integrated plan for the coordination and implementation of a unified CCEA program. This plan is designed to define the scope and elements of the unified CCEA, and identify specific outputs and milestones consistent with the CCEA goals and objectives. The plan also includes guidelines for implementing and administering the unified CCEA, recommendations for modifying various individual projects for consistency, and guidelines for the conduct of other initiatives as needed to fill selected gaps in current CCEA activities.

B. Program Plan Developmental Effort

The results of Tasks 1 and 2 yielded an impressive set of more than 500 ongoing and recently completed CCEA-related projects within EPA, other Government agencies, and nonprofit organizations. While analysis of this vast body of information is central to the process of establishing a comprehensive environmental assessment, the magnitude of such an undertaking is clearly beyond the scope of the current effort. Consequently, a manageable set of "core" projects are initially integrated into the unified CCEA to exemplify the methodology, and other efforts will be integrated as resources become available.

In order to reduce the number of CCEA-related projects for inclusion in the core set, several basic selection criteria were developed. Since the selection process was carried out on preliminary 
data, sone judgment in the use of these criteria had to be exercised. Five of the major criteria used for the selection of core projects are outlined as follows:

1. Since those programs funded by EPA have the greatest potential for influence by the CCEA program, a greater weighting should be given to EPA projects in selecting the core CCEA. The CCEA program, in order to be able to conduct a unified and coordinated environmental assessment, should have the capability to guide or redirect ongoing and future Räl efforts.

2. All projects selected should be ongoing or proposed since no redirection could be provided to past efforts.

3. Projects chosen should address a wide spectrum of environmental assessment areas such as input/output characterization and bioassay testing. Since the CCEA program planning is an effort to develop an overall coordinated structure, the core selection should reflect the diversity of information necessary for the comprehensive environmental assessment of conventional combustion processes.

4. Projects chosen should reflect the emphasis of current environsental assessment R\&D efforts. Priority should be given to heavily funded projects since funding levels usually indicate priorities established by the funding agencies. 
5. Projects chosen should have substantial information readily available. This criterion is utilized after the others have been applied in order to provide a manageable number of R\&D efforts for which a detailed analys is may be carried out.

The application of criteria 1 through 4, above, yielded a set of 32 relevant projects from which the core CCEA projects will be chosen. Table 3 shows the title, period of performance, sponsor, and EPA officer for each of the 32 projects. Criterion 5 was then applied to the above set to select the core for integration into the unified CCEA. *

The disaggregation of these projects was performed with the aid of an information checklist outlining the major elements (activities) of the cornprehensive environmental assessnent methodology. The checklist was used in identifying which of the EA elements were addressed by each of the projects. Thus, comparison between projects of the disaggregated information could delineate all the efforts addressing a single EA element.

\footnotetext{
* It is stressed here again that the limited set of projects selected for detailed evaluation is not intended as a complete representation of the wide range of research being pursued by the many agencies involved in environmental assessment activities. Rather, it presents the CCEA program planning methodology which will be used in integrating other projects as manpower and funding permit.
} 
TABLE 3

POTENTIAL EPA-SPONSORED CCEA CORE PROJECTS

\begin{tabular}{|c|c|c|}
\hline $\begin{array}{c}\text { PERIOD } \\
\text { OF PERFORMANCE }\end{array}$ & $\begin{array}{l}\text { PROJECT } \\
\text { OFFICER }\end{array}$ & TITLE \\
\hline $5 / 75-9 / 78$ & D. Kirchgessner & $\begin{array}{l}\text { Trace Element Characterization } \\
\text { and Removal/Recovery from Coal } \\
\text { Wastes }\end{array}$ \\
\hline $2 / 76-3 / 80$ & J.W. Jones & $\begin{array}{l}\text { Processing Sludges from Lime/ } \\
\text { Limestone Wet Scrubbing }\end{array}$ \\
\hline $1 / 76-12 / 79$ & R.A. Venezia & $\begin{array}{l}\text { Characterization of Effluents } \\
\text { from Coal-Fired Utility Boilers }\end{array}$ \\
\hline $4 / 77-$ & J.W. Jones & $\begin{array}{l}\text { Assessment of Effects of More } \\
\text { Stringent NSPS for Power Plant } \\
\mathrm{SO}_{2} \text { Emissions }\end{array}$ \\
\hline $12 / 75-4 / 78$ & W.S. Lanier & $\begin{array}{l}\text { Advanced Combustion Systems for } \\
\text { Stationary Turbine Engines }\end{array}$ \\
\hline $3 / 76-$ & J.W. Jones & $\begin{array}{l}\text { LG\&E Ful1-Scale Scrubber Testing } \\
\text { and Waste Disposal Program }\end{array}$ \\
\hline $1 / 76-$ & R.E. Hall & $\begin{array}{l}\text { Field Testing--Combustion Modifica- } \\
\text { tions of Industrial Combustion } \\
\text { Equipment }\end{array}$ \\
\hline $12 / 75-4 / 78$ & W.S. Lanier & $\begin{array}{l}\text { Advanced Combustion Systems for } \\
\text { Stationary Gas Turbine Engines }\end{array}$ \\
\hline $3 / 76-$ & J.W. Jones & $\begin{array}{l}\text { LG\&E Full-Scale Scrubber Testing } \\
\text { and Waste Disposal Program }\end{array}$ \\
\hline $3 / 76-3 / 79$ & L.D. Johnson & $\begin{array}{l}\text { Sampling and Analysis Methods } \\
\text { for POM and Other Organic } \\
\text { Pollutants }\end{array}$ \\
\hline $2 / 77-10 / 79$ & J.S. Bowen & $\begin{array}{l}\text { Environmenta } 1 \text { Assessment of } \\
\text { Stationary Source } \mathrm{NO}_{x} \text { Control } \\
\text { Technologies }\end{array}$ \\
\hline
\end{tabular}


TABLE 3 (Continued)

\begin{tabular}{|c|c|c|}
\hline $\begin{array}{c}\text { PERIOD } \\
\text { OF } \text { PERFORMANCE }\end{array}$ & $\begin{array}{l}\text { PROJECT } \\
\text { OFFICER }\end{array}$ & TITLE \\
\hline $1 / 77-8 / 78$ & G.B. Martin & $\begin{array}{l}\text { Design Optimization, Construction } \\
\text { and Field Optimization of Inte- } \\
\text { grated Residential Furnace }\end{array}$ \\
\hline $9 / 76-$ & L.E. Sparks & Evaluation of Hot Side ESP's \\
\hline $9 / 76-10 / 78$ & J.D. Kilgroe & $\begin{array}{l}\text { Combustion of Hydrothermally } \\
\text { Treated Coal }\end{array}$ \\
\hline $9 / 76-1 / 80$ & N. Kaplan & $\begin{array}{l}\text { Full Scale Utility Double Alkali } \\
\text { Demonstration }\end{array}$ \\
\hline $3 / 77-1 / 80$ & R.A. Venezia & $\begin{array}{l}\text { E/A of Conventional Combustion } \\
\text { Systems }\end{array}$ \\
\hline $9 / 76-$ & C.J. Chatlynne & $\begin{array}{l}\text { Advanced Regenerable FGD } \\
\text { Demonstration }\end{array}$ \\
\hline $1 / 77-$ & -- & $\begin{array}{l}\text { Effects of Pathogenic and Toxic } \\
\text { Materials Transported Via Cooling } \\
\text { Device }\end{array}$ \\
\hline $3 / 77-12 / 78$ & W.H. Ponder & $\begin{array}{l}\text { Comparative Multimedia Assessment: } \\
\text { Well-Controlled Coal-Fired \& } 0 i 1- \\
\text { Fired Boilers }\end{array}$ \\
\hline $3 / 77-7 / 79$ & J.H. Wasser & $\begin{array}{l}\text { Evaluation of Emissions and Control } \\
\text { Technology for Industrial Stoker } \\
\text { Boilers }\end{array}$ \\
\hline $3 / 77-6 / 78$ & L.E. Sparks & $\begin{array}{l}\text { Effects of Conditioning Agents on } \\
\text { Emissions from Coal-Fired Boilers }\end{array}$ \\
\hline $3 / 77-12 / 79$ & J.H. Wasser & $\begin{array}{l}\text { Environmental Assessment of After- } \\
\text { burner Combustion Systems }\end{array}$ \\
\hline $2 / 77-2 / 80$ & W.S. Lanier & $\begin{array}{l}\text { Fundamental Combustion Research } \\
\text { Applied to Pollution Control }\end{array}$ \\
\hline $3 / 77-7 / 78$ & J.W. Jones & $\begin{array}{l}\text { Study of Disposal of By-Products } \\
\text { from Non-Regenerable FGD Systems }\end{array}$ \\
\hline
\end{tabular}


TABLE 3 (Concluded)

\begin{tabular}{|c|c|c|}
\hline $\begin{array}{c}\text { PERIOD } \\
\text { OF PERFORMANCE }\end{array}$ & $\begin{array}{l}\text { PROJECT } \\
\text { OFFICER }\end{array}$ & TITLE \\
\hline $6 / 77-6 / 81$ & N. Kaplan & $\begin{array}{l}\text { Test Program for the Full Scale } \\
\text { Double Alkali FGD Utility Demon- } \\
\text { stration }\end{array}$ \\
\hline $5 / 77-$ & G.L. Johnson & $\begin{array}{l}\text { Fine Particle Emissions Infor- } \\
\text { mation System Development }\end{array}$ \\
\hline $6 / 77-$ & D.G. Lachapelle & $\begin{array}{l}\text { Evaluation of Pollutant Emissions } \\
\text { from Industrial Burners Using } \\
\text { "Dirty" Low and Medium BTU Gases }\end{array}$ \\
\hline $6 / 75-$ & J.W. Jones & $\begin{array}{l}\text { Evaluation of Alternatives for } \\
\text { Disposal of FGD Sludges }\end{array}$ \\
\hline $75-82$ & -- & $\begin{array}{l}\text { Advanced Particulate Control } \\
\text { Pilot Plant (ARAPAHOE) \& Technical } \\
\text { Field Support }\end{array}$ \\
\hline $7 / 75-7 / 78$ & G.E. Glass & $\begin{array}{l}\text { The Impact of Coal-Fired Power } \\
\text { Plants on the Environment }\end{array}$ \\
\hline $74-5 / 78$ & R.E. Hall & $\begin{array}{l}\text { The Effect of Combustion Modifi- } \\
\text { Cation on Pollutants and Equipment } \\
\text { Performance of Power Generation } \\
\text { Equipment }\end{array}$ \\
\hline $7 / 75-12 / 78$ & L. Smith & $\begin{array}{l}\text { An Integrated Assessment of } \\
\text { Electric Utility Energy Systems }\end{array}$ \\
\hline
\end{tabular}


In order to perform such comparison between projects and to later facilitate their integration in the unified CCEA program, a code corresponding to the elements of the EA methodology was developed and applied to the information in the checklist (Table 4). The code specifies whether the particular project merely identifies existing information on the EA element, develops or designs information on the EA element, or applies or performs the environmental assessment element.

In addition to the identification of environmental assessment elements addressed by each selected project, information regarding the specific pollution control technologies, pollutants, fuels, use sectors, and combustion processes/technologies involved is also necessary for comparative evaluation and future integration. Table 5 lists the codes utilized for use sectors, fuels, pollutants, and combustion processes/technologies; Table 6 shows the various categories of pollution control technologies.

The combination of the fuels (Table 5), use category (Table 5), pollution control technology (Table 6), media, environmental assessment element (Table 4), and pollutants (Table 5) describes completely all the areas included in a comprehensive environmental assessment of conventional combustion processes. It is the goal of the CCEA program planning effort to integrate ongoing projects and recommend new efforts to address all practical combinations of the above categories of information. 
TABLE 4

CCEA PROGRAM ENVIRONMENTAL ASSESSMENT ELEMENT CODE

MATRIX ENTRY NOTATION

(E).... Identify Existing Information or Define

(D)..... Develop Information or Design

(A)....Perform Activity (e.g.. Field or Lab Tests)

A...... Nerform Activity le.g.. Fiegative. Not Addressed

$\{x\}$..... Not clear from available information

(L) i.....Level I Analysis

L2 2 ....Level 2 Analysis

(L) .. Level 3 Analys is

(Lo)....Level other

COMBUSTION PROCESS TECHNOLOGY BACKGROUND

A1...State-of-the-Art Overview

DEVELOPMENT OF SAMPLING AND ANALYSIS TECHNIQUES

B1... Sampling Techniques

B2...Analysis Techniques

B3... Bioassay Techniaues

FUELS CHARACTERIZATION

Cl... Fuel Characteristics

C2...Type and Source

c3... Fuel Handling

C4...Availability

\section{INPUT-OUTPUT CHARACTERIZATION}

D1....Material Balance

Pollutant

FIELD TESTS AND SURVEYS

El...Control System Testing

E2...Combustion Process Testing

E3...Comprehensive waste Stream Characterization

- Level I Analysis

- Level 2 Analysis

- Level 3 Analysis

- Other Level of Analysis

POLLUTANT TRANSPORT, TRANSFORMATION, AND FATE MODELS

Fl...Modeling

F2....Meteorologic and Hydrologic Data

F3...Transformation Chemistry

F4....Exposure Level Calculations

DOSE-RESPONSE DATA

G1...Dose-Response Data Collection and Correlations ECOLOGICAL DATA

H1....Ecology-Related Impacts

H2....Air, Water and Land Ouality

H3....Quantified Media Degradation Alternatives EPIDEMIOLOG ICAL OATA

11... Industrial Related Heal th Data

I2... Increased Morbidity and Mortai ity

BIOASSAY DATA

J1...8ioassay Criteria

J2... Bioassay Techniques

33. . Control Process Stream Bioassay Data

EMISSIONS OR AMBIENT LEVEL GOALS

Kl...Permissible Media Concentration

K2. .. Criteria for Establishing Priorities

K3... Control Technology Limitations

K4,...MATE

SOCIAL/ECONOMIC/POLITICAL/IIISTITUTIONAL

DONSIDERATIONS

L1... Nonpollutant Impact Goals (Energy, Social, Economic, ete.

12.. Quantified Nonpoltueant Impacts and Siting

L3. ..critical Materiais impdets

\section{STATURORY CONSTRAINTS}

M1...Federal/State Standards and Regulations

M2... Research Data Base for Standards

Ambient Pollutant Levels

N1...Data Collection and Evaluation COMBUSTION PROCESS USE PROJECTIONS

01...Market Studies

02... Fuel Supply/Demand Projections

TOTAL POLLUTANT LOAD CALCULATIONS

P1...Process Load Calculations

P2...0ther Sources Load Calculations

P3... Natural Background

SYNERGISTIC AND MULTIMEOIA IMPACTS

Q1...Multimedia Pollutant Load Distributions Q2...Additive, Transformation, and Enhancement REGIONAL GEOGRAPHIC DATA

R1... Demographic Patterns and Trends

R2...Land Use Patterns and Trends

R3...Local hydrology

R4...LLocal Meteomiog

\section{POLLUTANT PRIORITY RANKINGS}

S1... Total Pollutant Load Calculations

S2...Degree of Hazard (Severity Indices)

CONTROL ALTERNATIVES

T....Add-on Devices

T2...Combustion Modification

T3... Fuel Mixing/Switching

CONTROL STRATEGY ENVIRONMENITAL IMPACTS

U1... Waste Disposal Options

U2... Secondary Environmental Impacts of Control Strategy

U3....Cross-Media Impacts CONTROL STRATEGY EVALUATION

V1...Control Assessment Criteria - Quantified Effluents and Costs

V2...Control Systems Economics

V3.... By-product Disposal Costs

V4... Energy Penalties

V5... Fuel Mix Availability

V6...Pollutant Removal Efficlency

V7.... Operational Availability

v8... Indus try Acceptance

v9... Source Analysis Models (SAM's)

STANOAROS OEYELOPMENT RECOMMENOATIONS

W...Standards Modifications Recommendations

W2... Standards Development Recommendations

W3. .. Criteria of Establishing Priorities

W... Recommendations for Schedules

CONTROL TECHNOLOGY DEVELOPMENT RECOMMENDATIONS

X1...Control Technol agy Modifications Reconmendations

X2... Quantifi ed Ro Needs

X3...Criterla for Estabishing Priorities

X4... Recormendations for Schedules 
USE SECTOR, FUELS, COMBUSTION PROCESS TYPE, COMBUSTION TECHNOLOGY, AND POLLUTANT CATEGORIES

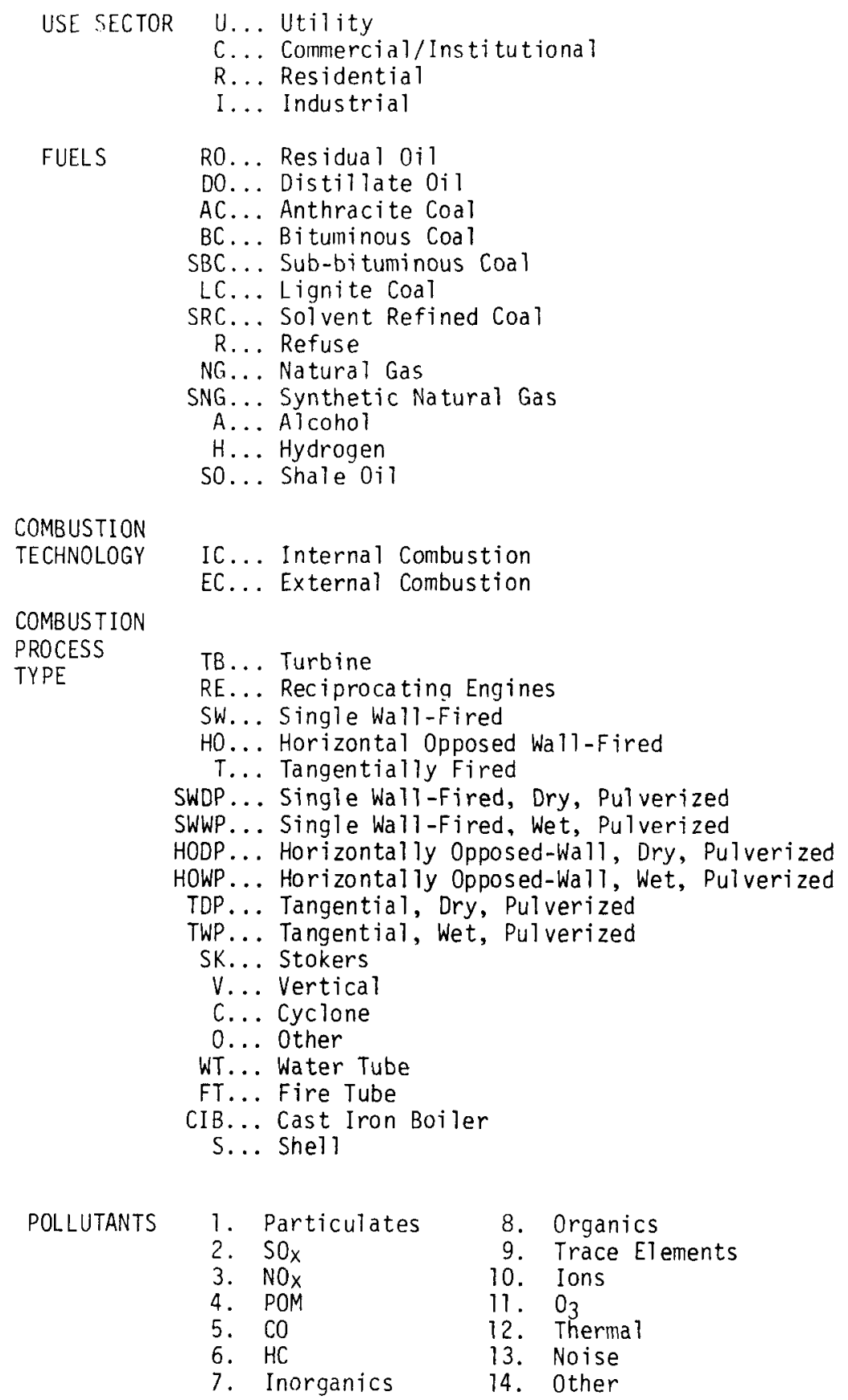


TABLE 6

POLLUTION CONTROL TECHNOLOGY CATEGORIES

Pollution Control Technologies

- Uncontrolled

- Air

- Water

- Land

- other

- Gas Treatment

- Mechanical Collection

- Electrostatic Precipitators

- Filters (fabric, granular, etc.)

- Liquid Scrubbers/Contactors (aqueous, inorganic, organic)

- Condensers

- Solid Sorbents (molecular sieves, activated carbon)

- Incineration (direct, catalytic)

- Liquids Treatment

- Settling, Sedimentation

- Precipitation, Flocculation, Sedimentation

- Centrifugation and Filtration

- Evaporation and Concentration

- Distillation, Flashing

- Liquid/Liquid Extraction

- Gas/Liquid Stripping

- Neutralization

- Biological oxidation

- Wet Thermal oxidation

- Activated Carbon Absorption

- Ion Exchange System

- Cooling Tower (wet \& dry)

- Chemical Reaction \& Separation

- Solids Treatment

- Fixation

- Recovery/Utilization

- Processing/Combustion

- Chemical Reaction \& Separation

- Oxidation/Digestion

- Physical Separation (specific gravity, magnetic, etc.)
- Final Disposal

- Pond Lining

- Deep Well Reinjection

- Burial and Landfill

- Sealed-Container Storage

- Dilution

- Dispersion

- Ocean Disposal

- Process Modification

- Feedstock Change/Fuel Treatment

- Stream Recycle

- Combustion Modification

- Flue Gas Recycle

- Water Injection

- Staged Combustion

- Low Excess Air Firing

- Optimum Burner/Furnace Design

- Alternate Fuels/Processes

- Accidental Release Technology

- Containment Storage

- Spill Cleanup Techniques 
Figure 10 describes the relationships between each of the above categories. With the type of CCEA program matrix shown in Figure 10, R\&D being conducted for any given fuel could be traced for each use sector, combustion technology/process, pollution control technology, media, environmental assessment element, and pollutant. Or, if one were interested in all the research being conducted by the CCEA program on a particular use sector, the CCEA matrix would facilitate a trace for any of the other parameters being addressed in terms of that use sector.

Figure 10 is a general diagram showing all possible combinations of factors considered in an EA. Figure 11 is an example which shows how all of the information from one of the core projects would be presented in the CCEA program matrix. This particular project is concerned with bituminous coal combustion in the utility sector. In particular, it addresses nine types of external combustion processes. Let us choose the research being conducted for combustion process SWDP--a Single-Wall-Fired, Dry, Pulverized unit. The matrix shows that the project is concerned with the environmental impacts on air, water, and land media of flue gas scrubbers attached to the SWDP unit, and of the waste disposal practices associated with the operation of the scrubber. Figure 11 shows that 14 EA elements are addressed by this project. Let us examine the research involved in element E3--comprehensive Waste Stream Characterization. Continuation of the trace shows that Level 2 analysis is being conducted for $\mathrm{SO}_{\mathrm{x}}$, trace elements, 


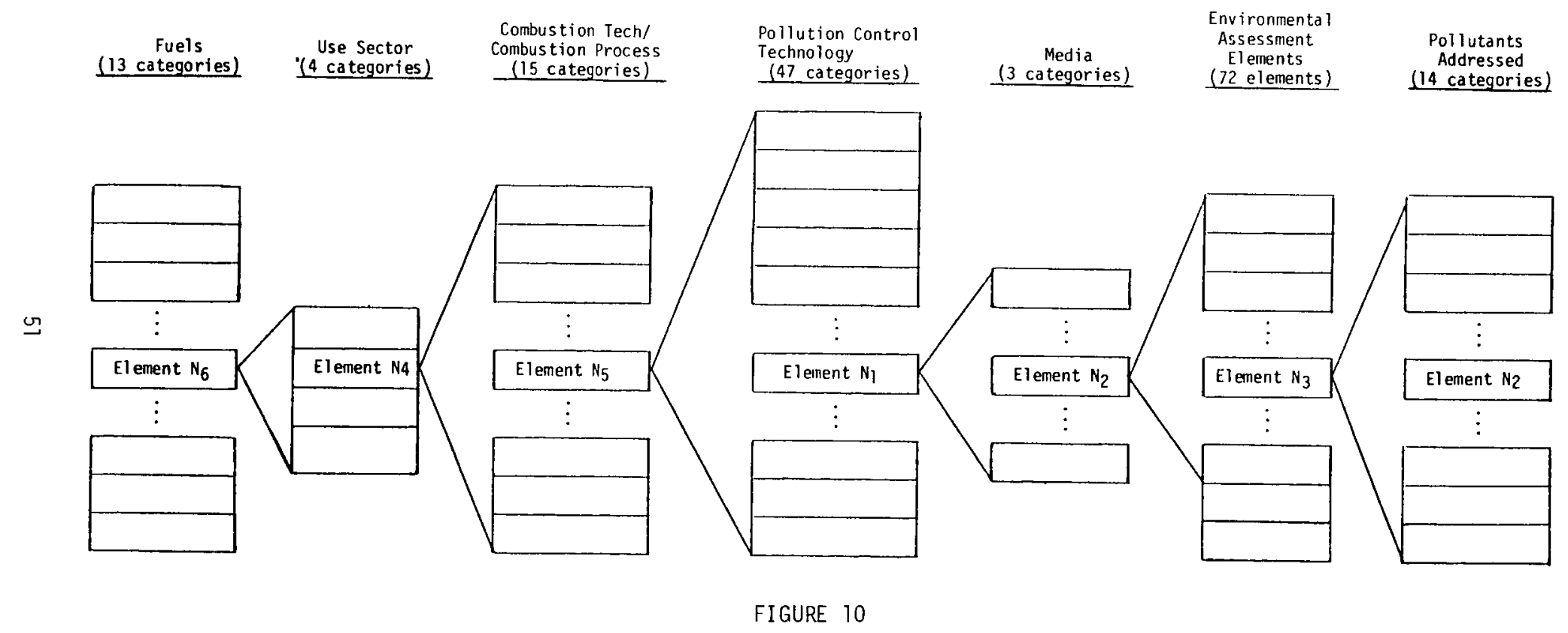

MATRIX OF ENVIRONMENTAL ASSESSMENT ELEMENTS 


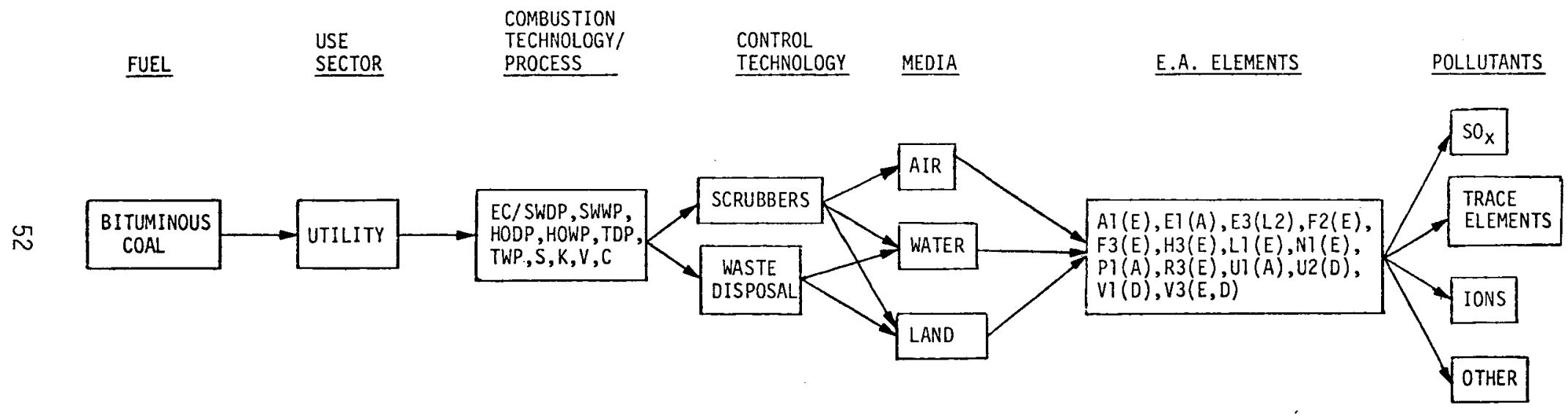

FIGURE 11

SAMPLE INFORMATION IN ENVIRONMENTAL ASSESSMENT MATRIX FORMAT 
and ions. Thus one could trace that the research being conducted on bituminous coal-fired utility SWDP unit using scrubbers includes Level 2 analysis for $\mathrm{SO}_{x}$ in the air media. Repetition of the above process for other pollutants and EA elements would summarize all the information content of this project.

When information from all the core projects is coded in the CCEA program matrix, the integration process (Task 4, Figure 9A) is essentially complete. The comparison between projects addressing similar EA elements, control technologies, pollutants, use sectors, combustion process/technology or fuel is relatively straightforward. This comparative evaluation identifies any potential overlaps that may exist between related efforts. Comparison of this integrated matrix with the goals and objectives of the unified CCEA (Tasks 5 and 6 ) identifies potential R\&D gaps that currently exist in the core CCEA. Reconciliation of the overlaps and new initiatives to fill gaps should complete the entire CCEA program matrix. This completed CCEA program matrix, then, would summarize the R\&D to conduct a comprehensive environmental assessment of conventional combustion processes.

\section{CCEA Program Planning Status}

The CCEA program planning effort has been completed. The identification and evaluation of related ongoing and proposed projects have resulted in the choice of approximately a dozen R\&D projects that are integrated to form the core, unified CCEA program. Potential program 
gaps and overlaps have been identified and recommendations for their resolution have been made. Goals and objectives for the unified CCEA have been developed and are currently being refined. Recommendations for implementing the program plan have been submitted to the EPA. A report describing results of this planning effort, including the unified CCEA program plan and recommendations for its implementation was submitted by MITRE/Metrek to EPA/IERL-RTP's Utilities and Industrial Power Division in July 1978. Efforts are now underway to select a systems contractor for the CCEA program. It is expected that EPA/IERL-RTP, with the assistance of contractors with experience and expertise in the various areas associated with the comprehensive environmental assessment of conventional combustion processes, will implement and expand the CCEA program as needs dictate and as resources permit in the coming months. 


\section{REFERENCES}

1. Independent Petroleum Association, "Report of the Supply and Demand Committee," 1976.

2. Executive Office of the President, Energy Policy and Planning, The National Energy Plan, U.S. Government Printing Office, Washington, D.C., April 1977.

3. M. Beller, ed., Sourcebook for Energy Assessment, Brookhaven National Laboratory, BNL-50483, 1977.

4. Energy Research \& Development Administration, "Inventory of Federal Energy-Related Environment \& Safety Research for FY 1976," Volume 1, April 1977.

5. R.P. Hangebrauck, "Briefing Notes for Meeting with ERDA, Fossil Energy," in-house document, EPA/Industrial Environmental Research Laboratory, Research Triangle Park, N.C., May 17, 1977.

6. J. Dorsey, L. Johnson, R. Statnick, and C. Lochmuller, Environmental Assessment Sampling and Analysis: Phased Approach and Techniques for Leve] 1, EPA-600/2-77-115 (NTIS No. PB 268563), June 1977.

7. J. Cleland and G. Kingsbury, Multimedia Environmental Goals for Environmental Assessment, Volumes I and II, EPA-600/ 7-77-136a/b, (NTIS No. PB 276919/276920), November 1977. 